\begin{tabular}{||ll||}
\hline Citation & Jan Baeten, Elena Marinova, Véronique De Laet, Patrick Degryse, Dirk De \\
& $\begin{array}{l}\text { Vos, Marc Waelkens, (2012), } \\
\text { Faecal biomarker and archaeobotanical analyses of sediments from a } \\
\text { public latrine shed new light on ruralisation in Sagalassos, Turkey } \\
\text { Journal of Archaeological Science, 39(4), 1143-1159. }\end{array}$ \\
\hline Archived version & $\begin{array}{l}\text { Author manuscript: the content is identical to the content of the published } \\
\text { paper, but without the final typesetting by the publisher }\end{array}$ \\
\hline Published version & $\underline{\text { http://dx.doi.org/10.1016/i.jas.2011.12.019 }}$ \\
\hline Journal homepage & $\underline{\text { http://www.journals.elsevier.com/journal-of-archaeological-science/ }}$ \\
\hline Author contact & $\underline{\text { dirk.devos@biw.kuleuven.be }}$ \\
\hline 32 (0)16 321639 \\
\hline IR
\end{tabular}

(article begins on next page) 



\title{
KULEUVEN
}

\section{Faecal biomarker and archaeobotanical analyses of sediments from a public latrine shed new light on ruralisation in Sagalassos, Turkey}

\author{
Jan Baeten ${ }^{a, b}$, Elena Marinova ${ }^{b}$, Véronique De Laet ${ }^{b, c}$, Patrick Degryse ${ }^{b}$, Dirk De Vos ${ }^{a, b}$, Marc Waelkens $^{b, d}$ \\ ${ }^{a}$ Center for Surface Chemistry and Catalysis, Katholieke Universiteit Leuven, \\ Kasteelpark Arenberg 23, 3001 Leuven, Belgium \\ ${ }^{\mathrm{b}}$ Centre for Archaeological Sciences, Katholieke Universiteit Leuven, \\ Celestijnenlaan 200E, 3001 Leuven, Belgium \\ ${ }^{c}$ Geography, Earth and Environmental Sciences, Katholieke Universiteit Leuven, \\ Celestijnenlaan 200E, 3001 Leuven, Belgium \\ d Department of Archaeology, Katholieke Universiteit Leuven, \\ Blijde Inkomststraat 21, 3000 Leuven, Belgium
}




\section{KU LEUVEN}

\section{Abstract}

A public latrine in the 'Imperial Baths' of Sagalassos was transformed into a dump site in the early Byzantine period. Several layers of urban waste, including ceramics, bones, glass and perhaps excrements were deposited on the floor. Faecal biomarker analyses and archaeobotanical analyses were conducted to reconstruct the history of the room. $5 \beta$-stanols of human origin, such as coprostanol, were found in the sewage channels together with mineralised plant remains, indicating a human faecal context. The botanical remains are furthermore representative of the Roman diet of the Sagalassians. Soil layers, deposited on top of the latrine floor and dating to the early Byzantine period, contained herbivore derived $5 \beta$-stanols,

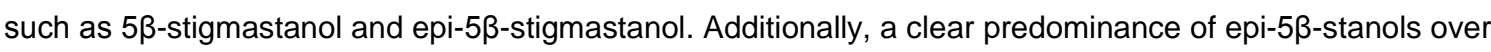
$5 \beta$-stanols showed that the animal dung has been subject to composting. In this period, the former latrine was clearly used as a manure production site which is further confirmed by stratigraphic evidence of large amounts of urban waste artefacts, which were commonly collected together with manure before application on the fields. The results of the present study support the theory that off-site potsherd scattering can be used as a proxy for manuring events. Additionally, the data show key evidence for vertical migration of $5 \beta$ stanols and presumably also for the leaching of bile acids.

\section{Keywords}

Manure; latrine; $5 \beta$-stanols; bile acids; faecal biomarkers; GC/MS; selected ion monitoring; macrobotanic remains; pollen; elemental analysis; ruralisation 


\subsection{Introduction}

Latrines, cesspits and other types of waste repositories provide a wealth of information on cultural, economic and environmental aspects of ancient civilisations. Apart from human or animal excrements, such contexts retain many artefacts reminiscent of ancient daily life such as pottery, food refuse, fodder, glass and coins (e.g. De Groote et al. 2004; Deforce 2010; Greig 1981; Knights et al. 1983; Tyson, 1996). Faecal remains and waste deposits can be studied by several approaches, dealing either with the identification of faecal matter in relation to the archaeological context, or to the taphonomic and diagenetic processes that affected the in situ preservation. Initially, mainly palaeobotanical analyses, i.e. the analysis of macrobotanical remains such as plant leaves, seeds and stems as well as pollen analysis, have been performed on such deposits (Greig 1981, 1982). There is also a large potential for their systematic microscopic investigation in order to elucidate questions on ancient trade, farming or gardening, diet, cooking and the environment (Deforce 2010; Martinez 2005; Oeggl et al. 2009; Ramsey and Tepper 2010). Another approach is the microscopic study of soils in thin sections, or micromorphology, which can provide identification of dung layers through observation of opal phytoliths, dung spherulites, calcium minerals and other dung related features (MacPhail et al. 2004; Matthews 2010; Shahack-Gross and Finkelstein 2008; Shillito et al. 2011b). Study of the taphonomic pathways affecting the preservation state of these features can provide information on herding strategies, transhumance, subsistence and other socio-economic themes (Shahack-Gross 2011). Inferences on the health status of ancient populations can be made by studying intestinal parasites (Reinhard 1992; Mitchell and Tepper 2007). The origin and diagenetic fate of dung-derived $\mathrm{C}$ and $\mathrm{N}$ pools is investigated by stable isotope analysis (Dungait et al. 2009, 2010; Ghosh et al. 2003; Shahack-Gross and Finkelstein 2008; Simpson et al. 1999a). Analysis of phosphate, one of the main indicators of human activity, and multi-element analyses are interpretative tools to elucidate patterns of human occupation and cultivation, such as the identification of middens, burial soils, cultivated farmlands and byres (Degryse et al. 2003; Entwistle et al. 2000; Farswan and Nautiyal 1997; Parnell et al. 2001; Simpson 1997). A more rigorous identification of faecal matter can be achieved by analysing faecal biomarkers (e.g. Bethell et al. 1994; Knights et al. 1983; Pepe et al. 1989; Pepe and Dizabo 1990). These markers are organic compounds derived from a faecal source, which retain their chemical structure during diagenesis (Bull et al. 2002). In addition to the identification of faecal material, they also provide information on their biogenic origin.

A first class of faecal biomarkers are $5 \beta$-stanols. Their presence in ancient coprolites and waste repositories has evidenced their persistence over several millennia, which enables their use in archaeological studies (Bull et al. 2005; Knights et al. 1983; Lin et al. 1978; Pepe et al. 1989; Pepe and Dizabo 1990). Their presence in coprolites of extinct mammals even demonstrates their use in Pleistocene research (Gill et al. 2009; van Geel 2008, in press). In addition, it has been experimentally confirmed that $5 \beta$-stanols persist in soils which received manure during a prolonged period (Bull et al. 1998; Evershed et al. 1997). Another group of faecal biomarkers are bile acids. Like $5 \beta$-stanols, bile acids have been shown to persist over several millennia in archaeological faecal deposits (Lin et al. 1978; Bull et al. 2005). Some authors even argue that they are more recalcitrant than 5ß-stanols (Bull et al. 2003; Elhmmali et al. 1997, 2000). Both groups of faecal biomarkers have been widely applied in archaeological studies. Human faeces, for example, have been identified in ancient cesspits, middens and latrines (Bethell et al. 1994; Bull et al. 2005; Pepe et al. 1989; Pepe and Dizabo 1990; Shillito et al. 2011a, 2011b), in a Roman fortification ditch (Knights et al. 1983) and in sediments from a Roman street drain (Bull et al. 2003). Also, the use of herbivore or porcine dung as manure for agricultural soils has been investigated (Birk et al. 2011; Bull et al.

Published version: http://dx.doi.org/10.1016/j.jas.2011.12.019 


\section{KU LEUVEN}

1999, 2001; Evershed et al. 1997; Simpson et al. 1999b). Recently, archaeol (a dialkyl glycerol ether) has been proposed as a biomarker for foregut fermentation in ruminants (Gill et al. 2010).

Numerous latrines from the Roman to Medieval period have been studied in Western Europe. Evidence from the Eastern Mediterranean and especially Anatolia, however, is still scarce. The current paper focuses on the analysis of latrine deposits from the Roman to early Byzantine town of Sagalassos, southwestern Turkey. The stratigraphy of the sediments provides indications for three use-phases. Architectural remains evidence that the room functioned as public latrine during its first phase. The functionality during later phases, however, is still unclear. Its use during Early Byzantine Sagalassos (mid $5^{\text {th }}-7^{\text {th }}$ century AD) is of particular interest as this period was a turning point in the city's history, which was marked by increasing ruralisation and ultimately urban decline. A multi-analytical approach, using analysis of faecal biomarkers, calcium analysis, macrobotanical remains, pollen and fungal spores, was chosen in order to achieve a more precise understanding on the use and maintenance of the studied structure. Particularly the combination of techniques has proven to overcome the limitations of each individual approach (e.g. Shillito et al. 2011b). More specifically, this paper aims at (i) identifying the presence and source of faecal remains, (ii) analysing the general organic (and inorganic) content of the structure and (iii) integrating these data to elucidate the different use-phases and associated maintenance policies of the structure.

\section{Study area}

\subsection{The site and its importance}

Sagalassos is located in southwest Turkey, in the Pisidian Lake District, at an altitude of $1450-1600 \mathrm{~m}$ a.s.I. in the Western Taurus mountains, approximately $110 \mathrm{~km}$ north of Antalya (ancient Attaleia) (figure 1). The natural assets of the territory, its strategic location, abundant water, fertile soils, availability of a variety of raw materials, and a major road connecting the city with the harbours on the Anatolian south coast fuelled the development of the city as a regional centre (Vanhaverbeke and Waelkens 2003). Under Roman Imperial rule (from ca. $25 \mathrm{BC}$ - mid 5th century $\mathrm{AD}$ ) the city flourished and became the most important town in Pisidia. The late Roman period (300-450 AD) witnessed the most intense exploitation of the city's territory. The first 100 years of the early Byzantine period (mid $5^{\text {th }}-7^{\text {th }}$ century AD) were still a period of prosperity in both city and countryside. Yet, over the course of the $5^{\text {th }}$ century, signs of stress on the city's subsistence patterns appear together with more intensive farming in the immediate vicinity of the city (Degryse et al., 2004). From the mid $6^{\text {th }}$ century AD onwards, there is increasing evidence of a ruralisation of Sagalassos, possibly coinciding with a decrease of the urban population and the probable abandonment of some quarters. From the onset of the excavations in 1990, attention was paid to monumental and architectural features as well as to interdisciplinary research, in order to better understand archaeological contexts in view of functional and social meaning, raw materials and the way they are treated, subsistence, human impact on the landscape and the palaeoenvironment. 


\subsection{Description of the latrine}

The studied profiles originate from one of the interconnected vaulted rooms supporting the imperial bath complex, built ca. 120-165 AD, i.e. room 4 (figure 2). This room measures approximately 8 by $10.5 \mathrm{~m}$ and has two windows. At the time of its discovery, room 4 was filled almost to its ceiling with mortar and small brick fragments from the covering of its concrete ceilings. The stratigraphy of the room was very complex and was described in more detail in previous records (Vermoere 2003, 2004). The presence of channelled stones at the original floor level and holes for fixing seats made it clear that the room had originally served as a public latrine (figure 2). The sewage channels, constructed alongside the room, served to collect human excrement and to drain them into the entrance of a sewer in the north-western corner of the room. The room was supplied with water which was recycled from the baths at the upper floor level and supplied to the room through a channel in the eastern wall (figure 2). The structure thus represents one of the best surviving examples of Roman greywater reuse.

At a certain point in the history of the room, as discussed below, the toilet seats were removed and the room served as a collector of waste material. Sediment layers excavated above the original floor level part of the stratigraphy is still present at locus A (figure 2) - contained a large amount of urban debris such as glass, coins, marble slabs, tesserae, metal, ceramics and animal bones, dating to the mid- $3^{\text {th }}$ to $6^{\text {th }}$ centuries AD. The fine ware ceramics found near the original floor level displayed traces of water abrasion and surface trampling, suggesting that the material was collected elsewhere and intentionally dumped here. Most of the bone material represented consumption refuse including bones from ovicaprines, cattle, pig, chicken and hare. Pollen analysis of these sediment layers complied with the stratigraphic evidence that waste material was collected from different parts of the city (Vermoere 2003, 2004). Mineralogical analysis by X-ray diffraction (XRD), conducted on the same sediment layers, furthermore indicated the possible addition of lime as revealed by the presence of mainly fine-grained calcite $\left(\mathrm{CaCO}_{3}\right)$ and minor amounts of portlandite $\left(\mathrm{Ca}(\mathrm{OH})_{2}\right)$ and lime $(\mathrm{CaO})$ (Patrick Degryse, pers. comm. 2008). In addition, the simultaneous occurrence of brushite and weddelite in certain layers could suggest a urinary origin (Daudon et al. 1998; Estepa et al., 1997), although these minerals might also originate from other sources or have been formed by mineralisation of organic material (McCobb et al. 2001, 2004). In the western part of the room, the floor level was raised twice in the course of the $7^{\text {th }}$ century AD (within a short period), demonstrating that this part of the room was once more in regular use. At the time of discovery, the room was completely filled with mortar and small brick fragments.

\section{$3 \quad$ Material and Methods}

\subsection{Coring and sampling of sediments}

Core profiles were taken at different locations within room 4, with sub-samples taken every $10 \mathrm{~cm}$. Three cores of about $60 \mathrm{~cm}$ depth each were taken from the stratified sediment heap that remained from the 1998 excavations (locus A, figure 2). Another two cores of $140 \mathrm{~cm}$ and $180 \mathrm{~cm}$ depth were taken using an Edelman corer from the sewage channel at loci $\mathrm{C}$ and $\mathrm{E}$, respectively. The sediments were divided into categories as depicted in figure 2. Soil pH was determined by suspending $5 \mathrm{~g}$ of soil into $25 \mathrm{ml}$ of $0.01 \mathrm{M}$ $\mathrm{CaCl}_{2}$ and measuring the $\mathrm{pH}$ of the resultant slurry. Six to seven samples were analyzed per locus (table 


\section{KU LEUVEN}

1). A summary of all sampled sediments is listed in table 1 along with the stratigraphic description and applied methods.

Charcoal fragments were isolated from four subsamples for obtaining radiocarbon dates. The ${ }^{14} \mathrm{C}$ ages were processed with accelerator mass spectrometry (AMS) after a standard acid-alkali-acid pre-treatment. The radiocarbon dates (table 2 ) are quoted in conventional ${ }^{14} \mathrm{C}$ years by correction for isotopic fractionation using $\delta^{13} \mathrm{C}$ values, and are calendar calibrated dates according to the INTCAL04 database (Reimer et al. 2004).

\subsection{Faecal biomarker analyses}

Extraction and purification of faecal biomarkers is based on a method described by Bull et al. $(1999,2001)$. We modified this procedure by using liquid-liquid extraction of the saponified lipid extract instead of the solid phase extraction to separate stanols and bile acids. This was achieved by extracting neutral lipids (including stanols) with hexane (2 to 3 times). The water content was then raised to $60 \%$ and after acidification (6M HCl, $\mathrm{pH} 3-4)$, polar lipids (including bile acids) were extracted with ethyl acetate (2 to 3 times). The solvent of both fractions was removed under a gentle stream of nitrogen. Subsequently, both fractions were derivatised with $\mathrm{N}$-methyl-N-(trimethylsilyl)trifluoroacetamide (MSTFA) with $1 \%$ trimethylchlorosilane (TMCS) at $60{ }^{\circ} \mathrm{C}$ for 1 hour yielding trimethylsilyl derivatives. After removal of solvent and excess reagent, neutral and polar fractions were redissolved in hexane and ethyl actetate, respectively. Both fractions were analysed with gas chromatography coupled to mass spectrometry (GC-MS) using an Agilent 6890 N GC instrument, equipped with a HP5-MS capillary column (30 m × 0.25 mm i.d. $\times 0.25 \mu \mathrm{m}$ film thickness) and coupled to an Agilent 5973 Network Mass Selective Detector. One $\mu$ of each fraction was injected in the splitless mode at a temperature of $290{ }^{\circ} \mathrm{C}$. The oven temperature was held at $150{ }^{\circ} \mathrm{C}$ for $2 \mathrm{~min}$, increased to $250^{\circ} \mathrm{C}$ at $20^{\circ} \mathrm{C} / \mathrm{min}$ followed by an isothermal $10 \mathrm{~min}$ hold and further ramped to 300 ${ }^{\circ} \mathrm{C}$ at $2{ }^{\circ} \mathrm{C} / \mathrm{min}$ followed by a isothermal hold of $20 \mathrm{~min}$ and a final ramp to $340{ }^{\circ} \mathrm{C}$ at $10^{\circ} \mathrm{C} / \mathrm{min}$. The mass spectrometer was held at a temperature of $340{ }^{\circ} \mathrm{C}$ and operated in scan mode (spectra were recorded between m/z 50 and 700) and in selected ion monitoring (SIM) mode. Peak assignments were made by comparison with retention time of authentic standard compounds and literature mass spectra. Reliable identification and quantification was achieved by adopting GC-MS/SIM as analytical technique. The diagnostic mass fragments used to detect target sterols and stanols are listed in table 3.

\subsection{Measurement of Ca concentration by elemental analysis}

The soil samples were first dried and finely ground. Calcium was then extracted in duplicate by digestion of $0.2 \mathrm{~g}$ soil material in $5 \mathrm{ml}$ of a mixture of $70 \% \mathrm{HClO}_{4}, 65 \% \mathrm{HNO}_{3}$ and $37 \% \mathrm{HCl}(1: 3: 1 \mathrm{v} / \mathrm{v} / \mathrm{v})$ in a microwave system (Milestone MLS 1200). Samples were subsequently diluted and concentrations of calcium were determined by atomic absorption spectroscopy (AAS, Solaar 969 AA).

\subsection{Macrobotanical analysis}

The average volume of the samples taken for the analysis of plant macrofossils comprised ca. $50 \mathrm{~cm}^{3}$. The samples were mixed with water for 12-24 hour in order to gently suspend them. The plant macrofossils 
were then recovered by wet sieving using sieve meshes of $1 \mathrm{~mm}$ and $0.3 \mathrm{~mm}$. The plant materials were sorted using a binocular microscope (Zeiss Stemi $2000 \mathrm{CS}$ ) and identified through comparison with the reference collections of the Centre for Archaeological Sciences, Katholieke Universiteit Leuven. The absolute numbers of counted plant remains per sample depths are represented in Table S2 and plotted in relation to the results of the biomarker analyses in figure 4.

\subsection{Analysis of pollen and fungal spores}

Samples of $3 \mathrm{~cm}^{3}$ were taken every 10 to $15 \mathrm{~cm}$ for pollen analysis. The samples were processed according to Faegri and Iversen (1989). Clay contamination was removed by ultrasonic sieving $(5 \mu \mathrm{m})$ although some pollen grains (Juniperus) could be lost by this procedure. Nevertheless, up to 250 pollen grains of terrestrial plants were counted. The pollen sum consists of terrestrial arboreal (AP, trees and shrubs) and non arboreal pollen (NAP, herbs) and excludes aquatic and marsh plants. Non-PollenPalynomorphs (NPP) were counted in the samples prepared for routine pollen analysis. The "types" identified, follow the type numbers described by van Geel $(1978,1986,2001)$ and van Geel et al. (1995, 2003). For calculation and diagram construction the programmes TILIA and TILIA GRAPH were used (Grimm 1991). The pollen diagram (in percentages) is depicted in figure 6.

\section{$4 \quad$ Results and discussion}

\subsection{Sediment description and radiocarbon dating}

In terms of stratigraphy, locus $A$ is situated above loci $C$ and $E$ and comprises 14 layers, subdivided into 6 different categories (figure 2, table 1). Category 1 comprises a heterogeneous reddish brown silt layer with charcoal, volcanic tuff and large ceramic fragments, and can be related to a dump context. The yellowish clay layers of category 2 serve as a key horizon and together with the sediments of category 3 they can probably be associated with lime addition (see also section 4.3). Categories 4 and 5 represent moister phases of activity (see also section 2.2) and the black organic rich clay layers (category 6) represent dry periods following inundation. At loci $\mathrm{C}$ and $\mathrm{E}$, ca. $30 \mathrm{~cm}$ of debris accumulation was found on top of a $90 \mathrm{~cm}$ thick light grey clay layer (figure 2). Below, at least $60 \mathrm{~cm}$ of dark grey organic rich clay is present (figure 2). Both clay layers contain a large number of small charcoal, ceramic and volcanic tuff fragments. From $30 \mathrm{~cm}$ onwards, the profiles of loci $C$ and $E$ are hypothesized to be related to latrine deposits, while the upper sections of profiles $C$ and $E$ and the profile at locus $A$ may be linked to the post-latrine use of the room.

The $\mathrm{pH}$ values of the sampled sediment layers are listed in table 1 . The $\mathrm{pH}$ range was rather narrow with values between 7.5 and 8.0. No significant differences between the different loci were observed.

Four samples of the different latrine deposits were chosen for AMS radiocarbon dating (table 2). The dates displayed an orderly relationship with depth, irrespective of the location of the samples. Two samples, taken from near the bottom of the sewage channel at locus $C$ (depth of $130 \mathrm{~cm}$ within the dark grey clay layer, figure 2) and $E$ (depth of $160 \mathrm{~cm}$ within the dark grey clay layer, figure 2), displayed an earlier date of AD 230-410 and AD 130-350 respectively, corresponding with the first phase of room 4, namely a public latrine. The latter date demonstrates that the latrine was already in use shortly after the construction of the 


\section{KULEUVEN}

'Imperial Baths' (120-165 AD) and was not a later $6^{\text {th }}$ century AD transformation as the excavators originally assumed (Waelkens et al. 2006). The remaining two samples, one from the stratified sediment heap that remained from the 1998 excavation (locus A, between 0 and $15 \mathrm{~cm}$ above original floor level) and another from the top level of the sewage channel (at $20 \mathrm{~cm}$ depth within the anthropogenic waste layer at locus $\mathrm{C}$ ), showed equal calibrated $(2 \sigma)$ dates of AD 420-600, corresponding with the second phase of room 4 . These observations match the stratigraphic observations in section 3.1.

\subsection{Faecal biomarkers}

The total lipid extracts of the latrine deposits contain a diverse set of lipids, including fatty acids, alkanols, alkanes, steroidal lipids, diterpenoids and pentacyclic triterpenoids. For the purpose of this study, only steroidal lipids, viz. sterols, stanols and bile acids, will be discussed.

Figure 3 depicts the identification of sterols and stanols by GC-MS/SIM in one sample from locus A (15 cm above present day surface) and one sample from the sewage channel (130 $\mathrm{cm}$ deep at locus $\mathrm{C}$ ). In almost all soil layers, $\Delta^{5}$-sterols, $5 \beta$-stanols, epi-5 5 -stanols and $5 \alpha$-stanols with carbon numbers between 27 and 29 could be identified. A summary of all identified steroids with their chemical structures and names is given in figure $\mathrm{S} 1$. The absolute concentrations of $5 \beta$-stanols range between $0.01 \mu \mathrm{g} \mathrm{g}^{-1}$ and $1 \mu \mathrm{g} \mathrm{g}^{-1}$ in the sewage channel (loci $\mathrm{C}$ and $\mathrm{E}$ ) (table S1). These values are consistent with reported data from a study of similar context and age (Bull et al. 2003). In contrast, the shallow sediment layers $(0-30 \mathrm{~cm})$ of locus $C$ and the samples from locus A contain a higher amount of $5 \beta$-stanols with concentrations up to $40 \mu \mathrm{g} \mathrm{g}^{-1}$. Bile acids, already extracted from similar contexts in our laboratory, were not detected in any of the latrine deposits.

The relative abundances of stanols and sterols in relation to depth are summarised in figure 4 . The stanol profile of locus $A$ exhibits a dominance of plant-derived $\mathrm{C}_{29}$ stanols $5 \beta$-stigmastanol, epi- $5 \beta$-stigmastanol and $5 \alpha$-stigmastanol, which together constitute about $81 \%$ of total sterols and stanols. Interestingly, $5 \beta$ -

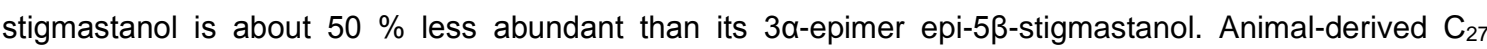
stanols such as coprostanol, epicoprostanol and $5 \alpha$-cholestanol were only present to a small extent (10 \% of total sterols and stanols). The shallow soil layers $(0-30 \mathrm{~cm})$ from the sewage channel core at locus $\mathrm{C}$ showed a strong resemblance with this pattern. The only difference was an increased abundance of sitosterol for the latter. In sharp contrast, the deep soil samples $(30-140 \mathrm{~cm})$ from this core profile displayed an enhanced presence of $\mathrm{C}_{27}$ steroids such as coprostanol, epicoprostanol, cholesterol and $5 \alpha$-cholestanol (30-45 \% of total sterols and stanols). The sewage channel core at locus E exhibited stanol profiles similar to the deep layers of locus $C$ with a pronounced dominance of animal-derived $\mathrm{C}_{27}$ steroids. A distinct pattern, however, is the elevated abundance of $5 a$-stigmastanol in the shallow soil layers $(0-40 \mathrm{~cm})$.

\subsubsection{Evidence for faecal derived $5 \beta$-stanols}

The presence of $5 \beta$-stanols, such as coprostanol and $5 \beta$-stigmastanol, in the latrine deposits provides a first indication of faecal matter, as they are products of the enteric hydrogenation of $\Delta^{5}$-sterols (Björkhem

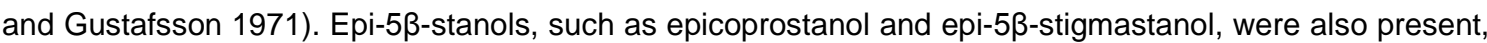
but are normally not abundantly present in fresh faeces (Leeming et al. 1996). They can however be found in soils as a result of microbially mediated epimerisation of 5ß-stanols (Mackenzie et al. 1982; McCalley et al. 1981). Unlike $5 \beta$-stanols, $5 \alpha$-stanols are not faecal biomarkers but are primarily formed by $\Delta^{5}$-sterol reduction under aerobic conditions (Gaskell and Eglinton 1975; Taylor et al. 1981). 
As $5 \beta$-stanols in sediments may also derive from a non-faecal origin, for instance as a result of sedimentary reduction of sterols, the interpretation of absolute concentrations of individual stanols is questionable (Bull et al. 2002). Therefore, the $[5 \beta:(5 \beta+5 \alpha)]$ stanol ratio has been established by studying modern-day sewage pollution (Grimalt et al. 1990). The value of 0.7 has been proposed as a lower limit for faecal pollution whereas values between 0.1 and 0.3 are representative for non-contaminated sediments. This ratio was further adapted by Bull and others (1999) to account for microbial and diagenetic changes that may affect the relative concentration of these biomarkers through time (Mackenzie et al. 1982; McCalley et al. 1981):

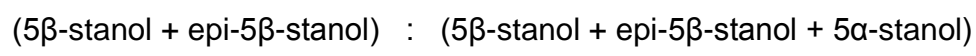

The values of this stanol ratio for the latrine sediments were plotted in function of depth, as depicted in figure 5a. The values have been calculated for both $\mathrm{C}_{27}$ stanols and $\mathrm{C}_{27+29}$ stanols, as ruminant dung is relatively enriched in $\mathrm{C}_{29}$ stanols such as $5 \beta$-stigmastanol (cf. infra) (Bull et al. 1999; Leeming et al. 1996). Values of the $C_{27}$ stanol ratio (1) above 0.7 were clearly observed in the sediments of locus $E$ and unambiguously demonstrate the faecal nature of the $5 \beta$-stanols. The $\mathrm{C}_{27+29}$ stanol ratios were notably lower in the top layers of this profile due to the enhanced concentration of $5 \alpha$-stigmastanol (figure 4) while a rapid increase to 0.7 was observed at depths below $60 \mathrm{~cm}$. At locus C, deep layers $(30-140 \mathrm{~cm})$ also displayed elevated values, ranging between 0.51 and 0.76 . However, both the upper layers $(0-30 \mathrm{~cm})$ from this core profile and the sediments from locus $A$ displayed distinctly lower $\mathrm{C}_{27}$ and $\mathrm{C}_{27+29}$ stanol ratios, with values around 0.45 and 0.55 respectively. These intermediate stanol ratios do not meet the faecal threshold of 0.7 as proposed by Grimalt and coworkers (1990). However, as Birk et al. (2011) have recently pointed out, this threshold was determined for urban sewage pollution in coastal waters and cannot be applied in general for archaeological sediments. Firstly, sedimentary reduction of $\Delta^{5}$-sterols can give rise to enhanced concentrations of $5 \alpha$-stanols due to the higher thermodynamic stability of the latter compared to $5 \beta$-stanols (Mackenzie et al. 1982; van Graas et al. 1982). Secondly, deposition of organic waste or litter fall would effect a rise in $5 \alpha$-stanol concentration and, consequently, a dilution of faecal derived $5 \beta$-stanols. Hence, the $[5 \beta:(5 \beta+5 \alpha)]$ stanol ratio in ancient sediments can be biased by diagenetic and post-depositional factors. Indeed, studies on Roman cesspits and ancient anthropogenic sediments report values of the stanol ratio (1) below 0.7 (Bethell et al. 1994; Bull et al. 1999; 2001).

Nevertheless, these arguments do not explain the discrepancy between the high values (above 0.7) of locus $\mathrm{E}$ on the one hand, and the intermediate values (around 0.5 ) of locus A and the top layers of locus $\mathrm{C}$ on the other hand. The dissimilar nature of these sediments was already observed in their stanol profiles: while animal derived $\mathrm{C}_{27}$ stanols were the major steroids in the former, plant-derived $\mathrm{C}_{29}$ stanols clearly predominated in the latter (figure 4). As herbivores ingest large amounts of plant matter, the predominance of $\mathrm{C}_{29} 5 \beta$-stanols can be attributed to the presence of herbivore dung (Bull et al. 1999b). This is further endorsed by the fact that herbivore dung is typically enriched in $5 \alpha$-stigmastanol concentrations leading to intermediate stanol ratios (Evershed et al. 1997; Leeming et al. 1996). By contrast, omnivore excrements are characterised by a dominance of $\mathrm{C}_{27} 5 \beta$-stanols and values of stanol ratio (1) above 0.7 . This was clearly observed in the sediments of locus $E$ as well as in some of the deep layers of locus $C$. In the latter, a slightly decreased $\mathrm{C}_{27}$ stanol ratio (1), with values between 0.6 and 0.7 , was observed between $50-120$ $\mathrm{cm}$ depth. In the following section, the biogenic origin of the $5 \beta$-stanols will be discussed in more detail. 


\section{KU LEUVEN}

\subsubsection{Evidence for human and animal $5 \beta$-stanols}

As herbivores ingest large amounts of plant-derived sterols, their excrements are enriched in $\mathrm{C}_{28}$ and $\mathrm{C}_{29}$ $5 \beta$-stanols such as $5 \beta$-campestanol and $5 \beta$-stigmastanol (Leeming et al. 1996). Therefore, the profile of faecal $5 \beta$-stanols allows for discrimination between herbivores and omnivores. In the light of this observation, the $C_{27} / C_{29} 5 \beta$-stanol ratio was proposed by Bull et al. (2001) and Evershed and Bethell (1996):

$$
\text { coprostanol : } 5 \beta \text {-stigmastanol }
$$

This ratio can be used as a proxy for the biogenic origin of $5 \beta$-stanols with values for humans and pigs ranging between 1.5 and 5.5, and values for ruminants being in the order of 0.25 .

In figure $5 b$ values of this stanol ratio are plotted in function of sample depth. Ratios of the core profile from locus E ranged from 1.06 to 3.45 with only shallow samples $(0-30 \mathrm{~cm})$ exhibiting values below 1.5 . The high values in the deep soil layers $(30-190 \mathrm{~cm})$ clearly indicate an omnivore origin of the $5 \beta$-stanols. By contrast, both locus $A$ and the top levels $\left(0-30 \mathrm{~cm}\right.$ ) of locus $C$ exhibited very low $C_{27} / C_{29}$ stanol ratios around 0.05 , thus confirming a herbivore origin of the stanols in these sediments. The deep layers $(30-140 \mathrm{~cm})$ of locus $\mathrm{C}$ displayed values of the stanol ratio (2) between 1.0 and 1.5 .

\subsubsection{Evidence for composting of faecal matter}

Another striking observation is the higher abundance of epi-5 $\beta$-stigmastanol compared to $5 \beta$-stigmastanol at locus $A$ and in the shallow soil layers $(0-30 \mathrm{~cm}$ ) of locus $C$ (figure 4$)$. The same pattern was noted for coprostanol and epicoprostanol at locus $A$. This can be illustrated by plotting the $3 \beta / 3 \alpha$-stanol ratio in function of depth (figure 5 c):

$$
(3 \beta, 5 \beta) \text {-stanol : }(3 \alpha, 5 \beta)-\text { stanol }
$$

McCalley et al. (1981) have shown that $(3 \beta, 5 \beta)$-stanols can be converted to their 3a-epimers during reworking in anoxic environments. Therefore, low $3 \beta / 3 \alpha$-stanol ratios $(<1)$, as observed for locus $A$ and for the shallow samples $(0-30 \mathrm{~cm})$ of locus $C$, indicate that the excrements have been subjected to composting. Similar observations were noted in Minoan terraces from Crete (Bull et al. 2001). In this study, the enhanced abundance of $3 \alpha$-epimers was interpreted as arising from predepositional reworking of faecal matter as the dry and arid conditions of soil formations of Crete are unlikely to promote such reactions.

In contrast, the omnivore excrements found in the sewage channel at locus E were not subjected to a similar composting process as the $3 \beta / 3 \alpha$-stanol ratio (3) displayed only values above 1.0. A similar pattern was observed for the $\mathrm{C}_{27}$ stanol ratio (3) of locus $\mathrm{C}$. In contrast, the latter core profile exhibits a gradual increase of the $\mathrm{C}_{29}$ stanol ratio (3) from values around 0.5 in the top layers towards values around 3.1 in the bottom layers. The latter will be further discussed in the following section.

\subsubsection{Indications for vertical migration of stanols}

The aforementioned stanol ratios unambiguously evidence the presence of composted ruminant dung at locus $A$ and in the upper layers of the sewage channel at locus $C$, and of non-composted omnivore faeces in the sewage channel at locus E. The deep layers $(30-140 \mathrm{~cm})$ of locus C, nevertheless, still exhibit some ambiguity. These layers exhibited a markedly distinct stanol profile in comparison with the superimposed herbivore dung layers (cf. figure 4), but also exhibited a number of dissimilarities with the stanol profile of 
locus $\mathrm{E}$. The relative concentration of $\Delta^{5}$-sterols, for instance, was generally higher in locus $\mathrm{C}$. Additionally, $\mathrm{C}_{27}$ and $\mathrm{C}_{29}$ stanols were almost equally abundant in locus $\mathrm{C}$, whereas locus $\mathrm{E}$ displayed a marked predominance of $\mathrm{C}_{27}$ stanols. This is surprising since both core profiles were taken from the same sewage channel and were only about $4 \mathrm{~m}$ located from each other. Similar ambiguities were found in the stanol ratios of the deep layers $(30-140 \mathrm{~cm})$ of locus $C$. The $[5 \beta:(5 \beta+5 \alpha)]$ stanol ratio (1) exhibited values between 0.6 and 0.7 . These values are situated between the values for herbivore and omnivore dung, as observed in locus $A$ and $E$, respectively. The $C_{27} / C_{29}$ stanol ratio (2) also furnished intermediate values close to the empirical threshold of omnivore faeces. A possible explanation would be that both herbivore and omnivore excrements were deposited in the sewage channel in the same period. However, the gradual increase of the $\mathrm{C}_{29}$ stanol ratio (3) suggests a second hypothesis, namely that stanols of the herbivore dung layers $(0-30 \mathrm{~cm})$ of locus $C$ infiltrated down the sewage channel and intermingled with stanols of omnivore excrements. This can be further illustrated by plotting the ratio of epi-5 $\beta$-stigmastanol, a marker for composted ruminant dung, to epicoprostanol, a marker for the non-composted omnivore dung (figure $5 \mathrm{~d}$ ):

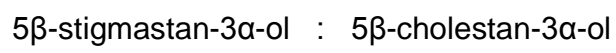

This stanol ratio (4) exhibits a marked inverse proportionality with depth. The data points were fitted with a power regression and yielded a correlation coefficient of 0.89 . Such a gradual concentration pattern is unlikely to result from a mixed deposition of herbivore and omnivore dung, but is rather indicative for the migration of ruminant stanols down the filling of the sewage channel. In addition, it would explain the intermediate values of the stanol ratios (1) and (2) in the deep layers (30-140 cm) of locus C.

Similar to locus $C$, an inverse proportionality of stanol ratio (4), with a correlation coefficient of 0.93 , was noted for locus $\mathrm{E}$ (figure $5 \mathrm{~d}$ ). This suggests that, although not suspected based on stanol ratios (1) and (3), a small amount of herbivore faecal stanols infiltrated in the upper part of this core profile. This vertical migration would further rationalise the intermediate values between 1.0 and 1.5 of stanol ratio (2) observed in the shallow layers $(0-30 \mathrm{~cm})$ of locus $\mathrm{E}$. The herbivore-derived stanols could have migrated either from sediments directly above locus $\mathrm{E}$ or from sewage channel deposits located east of this profile. The latter is possible since water entered the room through a channel in the eastern wall and flowed into the sewage channel towards the sewer entrance in north-western corner of the room (figure 2).

\subsection{Calcium analysis}

Several yellowish layers became apparent from the stratigraphy of the sediment cores, particularly in the soil profile at locus A (see photograph and stratigraphic category 2 in figure 2). Because of the possibility of lime addition it was decided to measure elemental concentrations of calcium. The results are depicted in figure 4. At medium depths $(30-140 \mathrm{~cm}$ ) in the sewage channels (loci C and E), the calcium concentration exhibited low values, namely between 50 and $80 \mathrm{mg} \mathrm{Ca} / \mathrm{g}$ soil. Conversely, the shallow soil layers from both cores and the soil layers from locus $\mathrm{E}$ below $1.5 \mathrm{~m}$ tended to be more enriched (up to $146 \mathrm{mg} \mathrm{Ca} / \mathrm{g}$ soil). All samples from locus A exhibited an even higher calcium concentration around $190 \mathrm{mg} / \mathrm{g}$ soil (figure 4). 


\subsection{Macrobotanical analysis}

The macrobotanical content of the sewage channel cores consisted predominantly of charred and mineralised plant remains. The co-occurrence of these types of plant remains indicates rather complex depositional conditions. They could have become incorporated into the deposits by flushing and subsequent perturbation of the sewage channel. The charred remains, including cereals (e.g. Triticum sp., Hordeum vulgare, Panicum miliaceum), lentils (Lens culinaris) and walnuts (Juglans regia), most probably derive from ashes, which were either thrown into the sewage channel as desiccant to prevent bad smell or discarded therein as waste. Of greater interest are the mineralised plant remains. Mineralisation can occur in archaeological contexts when organic matter is exchanged by calcium phosphate (McCobb et al. 2001, 2004). Roman latrines frequently exhibit such preservation conditions as calcium phosphate is an important constituent of faeces (Jacomet and Kreuz 1999). In addition to charred and mineralised plant remains, also fragments of strongly decomposed organic matter was present, particularly in the lower part $(70-170 \mathrm{~cm})$ of locus E. Although these fragments could not be identified, the presence of such highly decomposed matter suggests that this part of the sewage channel was subject to water logging.

The identified mineralised seeds in the sewage channel profiles, viz. fig (Ficus carica), plum (Prunus sp.) and grape (Vitis vinifera), constitute a number of frequently recorded species in the Roman food chain (Kuijper and Turner 1992; White 1970) and were also quite common in Sagalassos during the Roman and early Byzantine period. Most of these remains are primarily used for human consumption rather than for fodder, and thus make up an important part of the diet of the Sagalassians from the $2^{\text {nd }}$ to $5^{\text {th }}$ century AD. Notably, pits of olives, which represent an important element of Roman agriculture and diet, were not found in the latrine deposits. This is remarkable since other fruit stones, such as Prunus sp., were present and would generally preserve in a similar manner as olive pits. Most probably, olives were not a very common component in the diet of the Sagalassians as archaeobotanical analyses of Roman to early Byzantine urban contexts show that charred olive stones only account for ca. $3 \%$ of the total amount of investigated plant remains. Finally, mineralised remains of spices were also found in the lower part for locus $\mathrm{C}$ (Table S2), such as the inner part of probably coriander and dill. Both condiments were rather popular for Roman food preparation (Prance and Nesbitt 2005 and references therein). Their occurrence and preservation in mineralised state is strong evidence for the presence of human faeces in the studied sediments and correspond to the first phase of room 4, namely a public latrine.

Apart from plant macroremains also some small animal remains were found. However, only few of them could be identified and included one bone of a micro-mammal and six fish remains, i.e. 1 rib, 3 scales and 2 pharyngeal plates from very small cyprinids (130-140 cm deep at locus C and 160-170 cm deep at locus E). All other fragments (66 in total) are small pieces of bird and mammal bones, which remained unidentifiable. Traces of digestion (or the effect of gastric juices) are not clearly visible on these bones. It is therefore questionable but not excluded that the bones have passed through the digestive tract (Bea De Cupere, pers. comm. 2010).

\subsection{Pollen analysis and fungal spores}

Pollen preservation of the studied profiles was mainly limited to the lower part $(70-170 \mathrm{~cm})$ of locus E. The pollen found, moreover, generally represent the vegetation in the surrounding of the sampled location and are to a much lesser extent representative of human food (figure 6). This is most probably due to an influx of local and regional pollen with water percolating through the sewage channel. Several of the pollen taxa, 
belonging to the group of "cultivated" species, originate from trees that most probably grew in the city, such as chestnut (Castanea), hazel (Corylus), walnut (Juglans) and plum (Prunus). Finds of hazel, walnut and plum are common vegetation elements of this site as they appear also in wood charcoal assemblages from the Early Byzantine period. These species were furthermore exploited for alimentary purposes (see for instance Poblome et al. 2008; Romanus et al. 2009). Of particular interest are the NPP pollen that are indicative of the local conditions in the deposits. The fungal spores of Cercophora-type and Sordaria-type, for instance, found between $70 \mathrm{~cm}$ and $120 \mathrm{~cm}$ depth in profile $\mathrm{E}$, have coprophilous affinity and are usually associated with dung (van Geel et al. 2003). Most of the other pollen types correspond to the ruderal vegetation of the site and the surrounding open spaces and woodland. These results are in good agreement with the previous pollen analysis on sediments from the same room (see section 2.2 and Vermoere et al. 2003).

\subsection{Reconstruction of the three use-phases of room 4}

In this study, we adopted multiple approaches to gain a detailed insight in the content and functionality of room 4 of the 'Imperial Baths' of Sagalassos. In line with the primary objectives of this study, clear evidence of faecal remains was found by faecal biomarker analysis. Secondly, botanical and animal remains along with inorganic matter provided further insights on the general content of the deposits. The results of these analyses, together with contextual evidence, radiocarbon dates and the stratigraphy, will now be integrated to reconstruct the three use-phases of room 4.

\subsubsection{The first phase: a public latrine}

The first phase of room 4 is clearly associated with the function of public latrine, as pointed out by the architecture of the vaulted room (see section 2.2). The construction enables the cleaning of the channel by flushing periodically with large amounts of water that was recycled from the baths on the upper floor levels. This is also visible in the pollen composition of the sewage channels, representing the wild growing vegetation, predominantly woodland and open vegetation, in the surrounding of the 'Imperial Baths' (figure 6). Nevertheless, water logging must also have occurred, at least partly, as suggested by the presence of strongly decomposed organic matter in the sewage channel profile at locus E. This event, however, may also have happened after the function of latrine was abandoned.

The radiocarbon dates of the lowest sample of the sewage channel at locus E (130-350 cal AD) showed that the latrine was already in use shortly after the construction of the baths in 120-165 AD. Conclusive evidence for faecal remains was provided by the presence of faecal biomarkers, viz. $5 \beta$-stanols, in the sewage channel (loci $C$ and $E$ ). The stanol ratios of the deep layers are rather uniform and thus confirm that no significant change in faecal deposition has taken place. The $[5 \beta:(5 \beta+5 \alpha)]$ stanol ratios in the deep sediments of the sewage channel cores displayed values between 0.6 and 1.0 and were interpreted as deriving from faecal matter (figure $5 \mathrm{a}$ ). Despite recent criticism on the applicability of this stanol ratio for the assessment of ancient manuring events (Birk et al. 2011), these values sustain the validity of this ratio in concentrated faecal deposits such as latrines. The coprostanol : $5 \beta$-stigmastanol ratio of these layers exhibits values above 1.5 and indicates an omnivore faecal deposition, most probably from humans (figure 5b). Apart from faecal biomarkers, the sewage channel also contained traces of consumption refuse. These include macroscopic seeds of cereal grains, lentils, beans, figs, walnuts, plums, grapes, and inner parts of spices, probably coriander and dill. Many of these remains were found in the mineralised state confirming a 
human faecal context (Jacomet and Kreuz 1999). The recorded species represent common elements Roman crop husbandry and arboriculture (Kuijper and Turner 1992; White 1970) and also occur frequently in the archaeobotanical finds in Roman to early Byzantine Sagalassos. Also, the presence of coprophilous fungi in the deep layers of the sewage channel provides clear evidence that the deposits are indeed associated with a faecal context (van Geel et al. 2003).

The high concentration of charred plant remains may result from the disposal of ashes into the channel. Alternatively, the chars might have been discarded therein on purpose. Wood ash is a desiccant and raises the $\mathrm{pH}$, which has the joint effect of reducing odours and destroying pathogens (Mehl 2011). Similar practice was done in Roman kitchens where ashes from the stove were thrown into a cesspit to neutralise the smell (Scobie 1986). Furthermore, the lowermost layers (150-190 cm depth) of the sewage channel (locus E) display a distinct increase in calcium concentration, which may indicate that lime was added. Lime has similar properties as wood ash and therefore, these observations could indicate that Sagalassians have used both ashes and lime to improve the operation and sanitary conditions of the public latrine.

\subsubsection{The second phase: a manure producing unit}

At a certain point in the history of Sagalassos, the function of public latrine was abandoned. It was shown by radiocarbon dating that this transition occurred in the early Byzantine period (see below). The latrine seats were removed and the original floor was covered with several layers of sediments. The stratigraphy of these layers was complex and contained a large amount of urban waste. Preliminary analyses suggested that the room was used as a collector of excrements, as some layers indicate the presence of both brushite and weddelite. While these minerals may be linked to a urinary origin, other sources or in situ mineralisation (McCobb et al. 2001, 2004) can not be excluded. The present study, however, provides robust evidence of herbivore derived $5 \beta$-stanols in both the uppermost layers $(0-30 \mathrm{~cm} \mathrm{depth})$ of the sewage channel (locus $C$ ) and the stratified heap (locus $A)$. Values of the $[5 \beta:(5 \beta+5 \alpha)]$ stanol ratio around 0.5 were slightly lower than the sewage channel layers that contained human faeces, even though absolute concentrations of faecal biomarkers were higher (table S1). These lower values were found to be inherently related to the herbivore origin of the faecal biomarkers (Evershed et al. 1997; Leeming et al. 1996). Indeed, values of the coprostanol : $5 \beta$-stigmastanol ratio around 0.25 evidenced the presence of herbivore dung. Moreover, the predominance of epi-5 $\beta$-stanol over $5 \beta$-stanols at locus A (figure $5 \mathrm{c}$ ) provides evidence that the herbivore dung has been subject to intensive bacterial reworking, which could have occurred during the composting of the dung. A small contribution of porcine dung, however, cannot entirely be ruled out as bile acids were not detected (cf. Bull et al. 2002, see below). Yet, its proportion must have been rather limited since pigs only constituted between 20 and $30 \%$ of the livestock of Sagalassos during the Roman and Early Byzantine period (De Cupere, 2001).

The production of a fuel composed of dried animal dung can be ruled out since the well-constructed water supply to the room does not provide suitable drying conditions. Another hypothesis would be that the room was used as a stable. However, the complex stratigraphy containing different types of urban waste, the intensive microbial reworking of the ruminant dung and the addition of a calcium source do not support this functionality. In fact, such a deposit is more likely to be associated with a manure producing unit.

First of all, the scattering of potsherds in ancient off-site agricultural soils is considered as a marker for manuring. This theory was first proposed by Wilkinson (1982) and further strengthened by Bintliff and Snodgrass (1988). This theory entails the collection of animal and human excrements together with household rubbish, which was regularly spread across the cultivated landscape as fertiliser and, after iterated application, produces a pattern of scattered off-site potsherd distributions. Bull and co-workers 
(2001) have validated this theory for manuring practices on Minoan agricultural terraces by the combined study of off-site potsherd scattering and faecal biomarker analysis. The present study further supports this theory by delivering the first evidence, based on faecal biomarker analyses, of the collection of excrements together with household waste in a manure production site. Indeed, the latrine deposits excavated above original floor level were associated with a large amount of urban waste, e.g. ceramics, animal bones, coins, glass, marble slabs, tesserae and metal artefacts. The fine ware ceramics found near the original floor displayed traces of water abrasion and surface trampling, suggesting that the material was collected elsewhere and dumped here. This was also observed in the sediments sampled for the current study, where many ceramic fragments were observed in the layers that contained the ruminant dung (figure 2, locus $\mathrm{A}$ and top $30 \mathrm{~cm}$ of locus $\mathrm{C}$ ). However, further analyses are required to assess the application of such a mixed deposit to the farmlands of Sagalassos.

Secondly, the predominance of 3a-epimers in the herbivore dung layers (figure $5 c$ ) shows that the animal dung was subject to composting. This practice has already been observed in Minoan agriculture (Bull et al. 2001) and the importance of decomposition of organic matter to release its nutrients in arid or semi-arid regions was also recognised by ancient agronomists such as Varro, Columella and Pliny (White 1970). Columella, for instance, points out that an ample supply of moisture will ensure complete decomposition, while turning over the entire compost heap with drag-hoes will facilitate aerobic decay. The former latrine of the 'Imperial Baths' fulfils all of these conditions as a water channel would have supplied enough moisture to the room and the vaulted room must have shielded the rotting manure from direct sunlight.

Thirdly, the stratigraphy of locus A (figure 2) exhibited yellowish layers alternated with black organic layers. The yellowish layers most probably witness the addition of lime layers to the dump as indicated by preliminary mineralogical analysis (cf. section 2.2). Measurement by elemental analysis demonstrated that these deposits indeed contained much higher calcium concentrations than the sediments from the sewage channel (figure 4), supporting the hypothesis that lime was added to the dung layers. Liming is a well known practice in Roman agriculture (White 1970). Applying lime directly to the soil has the dual benefit of making up for calcium deficiencies and correcting undue acidity. Moreover, lime is also a desiccant and increases the $\mathrm{pH}$ (cf. supra). Similar practice is still common in many rural settings.

The deposits associated with the second use-phase, i.e. locus $A$ and top $30 \mathrm{~cm}$ of locus $C$, were dated to 420-600 cal AD (table 2). This corresponds to the early Byzantine period in Sagalassos which was characterised by stress on the city's food supplies. Macrobotanic records of the city show that, from the $5^{\text {th }}$ century $A D$ onwards, farming activities such as threshing occur close to the city proper and that millet and barley, crops thriving on higher and poorer soils, is increasingly cultivated in different parts of the city (Thijs Van Thuyne, unpublished results). Furthermore, a diachronic assemblage of domestic animal bones from consumption deposits showed a marked increase in heavy metal concentrations for cattle and ovicaprines in the $5^{\text {th }}$ to $6^{\text {th }}$ century $A D$, indicating that the consumed meat no longer belonged to animals living, grazing or working in the countryside, but in the immediate vicinity of the city (Degryse et al. 2004). In the same period, a vaulted room in the palatial mansion of the city was transformed into a room that either served as a small stable or was used to store dried dung cakes.

These signs of ruralisation in the early Byzantine period correspond very well with the results of the present study. Dung from herbivores, held within the city proper, was collected in the former latrine of the 'Imperial Baths' and was allowed to compost. The resulting manure could then be applied as a fertiliser on farmlands in the immediate vicinity of the city. Although the profile of $5 \beta$-stanols does not allow further distinction within the group of herbivores, manure of cattle was considered as unimportant and is rated below the nitrogen-rich manures of sheep and goat by Roman agronomists (White 1970). Furthermore, an estimate of the magnitude of manure production can be made, based on the recommendations of Columella for 


\section{KU LEUVEN}

farming in Italy: 18 to 24 vehes of manure should be applied per iugerum which corresponds to 36 to 48 tons per ha in modern units (White, 1970). Supposing a $1 \mathrm{~m}$ thick compost layer was stored in room 4 (8.05 $\mathrm{m} \times 10.48 \mathrm{~m}$ ), manure could have been produced for about 1.75 to 2.25 ha. Similar ratios might be valid for Sagalassos. This implies that compost was produced for small-scale agricultural activities in the vicinity of city.

\subsubsection{The third phase: abandonment?}

In the course of the $7^{\text {th }}$ century $A D$, the floor level of the former public latrine was raised twice in the western part of the room, demonstrating that this part of the room was once more in regular use. The floor levels consisted of horizontal tiles and cobbles, but were not associated with find assemblages. Therefore, the surface was probably not used intensively or over a long period of time. In 600-620 AD, an earthquake with its epicentre in or near the city resulted in its total destruction. From the second quarter of the $7^{\text {th }}$ century until the mid $13^{\text {th }}$ century $A D$, some isolated hamlets survived among the ruins. During this period, the countryside still seems to have held more villages than previously assumed (Waelkens et al. 2006). Yet, ongoing palynological research suggests a transition of farming to pastoralism in at least some of the valleys within the city's former territory around 650 AD (Bakker, unpublished results). While village life persisted in the $8^{\text {th }}$ to $13^{\text {th }}$ century $A D$, Sagalassos was completely abandoned around the middle of the $13^{\text {th }}$ century AD.

\subsection{General implications for faecal biomarker analysis}

Apart from the primary objectives, further remarkable observations contribute to the understanding of lipid biomarkers in soils and their diagenesis. One of these observations is the apparent infiltration of $5 \beta$-stanols down the sewage channel, as demonstrated by the fact that the abundance of epi-5 $\beta$-stigmastanol decreased with depth relative to epicoprostanol (figure $5 \mathrm{~d}$, loci $\mathrm{C}$ and $\mathrm{E}$ ). This can most likely be explained by the infiltration of composted ruminant dung down the sewage channel, where it intermingled with human excrements. Similar observations were already made in a Roman cesspit from Stanwick where faecal signatures, based on $5 \beta$-stanols, were obtained underneath the cesspit (Bethell et al. 1994). Another remarkable fact is that bile acids were not detected in the present latrine deposits. This is a remarkable observation since bile acids are generally considered more recalcitrant than $5 \beta$-stanols (Elhmmali et al. 1997, 2000; Bull et al. 2003). A feasible explanation would be that they have completely leached out of the sediments. Whereas stanols are relatively insoluble, approximately $0.5-1.8 \mu \mathrm{g} / \mathrm{l}$, the solubility of bile acids much higher. The solubility of the latter is furthermore increased in alkaline conditions due to their weak acid functionality (table S3). The latrine deposits under study exhibit rather uniform pH values between 7.5 and 8.0. Bile acids are quite soluble in such a slightly alkaline environment. For instance, deoxycholic acid has a solubility of $2.7 \mathrm{~g} / \mathrm{l}$ at pH 8.0 (table S3). Therefore, the complete leaching of the bile acids would be a very reasonable explanation for the failure to detect them. This recognition poses a limitation on the use of bile acids as faecal biomarkers in neutral to alkaline soils which are subject to extensive water percolation. A similar mechanism might be valid for other compound classes bearing acid functionalities. The observed infiltration of stanols, however, seems to require another explanation since these compounds are far less soluble and thus less prone to leaching. But very little is known about the long-term effects of water percolation and environmental factors that influence leaching. Perhaps these molecules were transported 
by a downward physical migration of colloidal soil particles. This may be further promoted by action of soil fauna living in the upper soil horizons.

\section{Conclusion}

Faecal biomarker and archaeobotanical analyses were conducted to reconstruct the use and maintenance of the public latrine of the 'Imperial Baths' of Sagalassos. The presence of human derived $5 \beta$-stanols, such as coprostanol and epicoprostanol, in the sewage channel provided unambiguous evidence for human excrements. Radiocarbon dating shows that the latrine was already in use shortly after construction of the 'Imperial Baths' in 120-165 AD. Macroscopic plant remains and pollen, recovered from the sewage channels, represent a number of common species of the Roman diet in Sagalassos. Interestingly, deposits above the original floor of the latrine, dating to the early Byzantine period, contained clear evidence of ruminant dung, based on the presence of plant derived $5 \beta$-stanols, such as $5 \beta$-stigmastanol and epi-5 $\beta$ stigmastanol. The predominance of epi-5 $\beta$-stanols over $5 \beta$-stanols in these layers further indicates that the animal dung has been subject to intensive bacterial reworking. Therefore, it can be assumed that the former latrine was reused as a manure production site. This hypothesis is further sustained by the indications for lime addition based on stratigraphic evidence, mineralogical analyses and elemental calcium analysis. This may have been done to improve the quality of the compost heap as lime acts as a desiccant, increases the $\mathrm{pH}$ and thus suppresses bad smell released from the digesting manure. The reuse of the former latrine as a manure producing facility is congruent with the history of the city of Sagalassos, which was characterised by increasing ruralisation from the early Byzantine period onwards.

Furthermore, the animal dung layers were clearly associated with large amounts of urban waste such as ceramics. Upon repeated application on agricultural fields, this would result in a pattern of scattered distribution of potsherds, which may be considered as a proxy for manuring events. While this theory has already been validated by the presence of faecal biomarkers in suspected manured farmlands, the current study presents evidence, for the first time, that animal waste and household waste were disposed in the same place. Further analyses, however, are required to assess the effective application of this suspected manure to the farmlands of Sagalassos.

Novel perspectives on the preservation and diagenesis on faecal biomarkers were also drawn from the present data set. A remarkable failure to detect bile acids was rationalised by their increased water solubility in alkaline environments. Finally, $5 \beta$-stanols also exhibited a susceptibility to vertical migration. Yet, the exact mechanisms are not fully understood and require further investigation.

\section{Acknowledgements}

This research was made possible thanks to the permission and under the supervision of the General Directorate for Antiquities (Turkish Ministry of Culture). It was financially supported by the Belgian Programme Interuniversitary Poles of Attraction (IAP 6/22) and the Research Fund of the K.U.Leuven (BOF-GOA 07/02), next to project G.0421.06 of the Fund for Scientific Research, Flanders (FWO). M. Waelkens is a beneficiary of a Methusalem grant of the Flemish Government. We are also very grateful to Sabina Accardo, Jacqueline Vancluysen and Steven Luypaers for their technical assistance and to Bea De Cupere for the analysis of the archaeozoological remains.

Published version: http://dx.doi.org/10.1016/j.jas.2011.12.019 


\section{REFERENCES}

Bethell, P.H., Goad, L.J., Evershed, R.P., 1994. The study of molecular markers of human activity: the use of coprostanol in the soil as an indicator of human faecal material. J. Archaeol. Sci. 21, 619-632.

Bintliff, J., Snodgrass, A., 1988. Off-site pottery distributions: a regional and interregional perspective. Curr. Anthropol. 29, 506-513.

Birk, J.J., Teixeira, W.G., Neves, E.G., Glaser, B., 2011. Faeces deposition on Amazonian Anthrosols as assessed from 5 $\beta$-stanols. J. Archaeol. Sci. 38, 1209-1220.

Björkhem, I., Gustafsson, J., 1971. Mechanism of microbial transformation of cholesterol into coprostanol. Eur. J. Biochem. 21, 428-432.

Bull, I.D., van Bergen, P.F., Poulton, P.R., Evershed, R.P., 1998. Organic geochemical studies of soils from the Rothamsted Classical Experiments - II. Soils from the Hoosfield Spring Barley Experiment treated with different quantities of manure. Org. Geochem. 28, 11-26.

Bull, I.D., Simpson, I.A., Dockrill, J., Evershed, R.P., 1999. Organic geochemical evidence for the origin of ancient anthropogenic soil deposits at Tofts Ness, Sanday, Orkney. Org. Geochem. 30, 535-556.

Bull, I.D., Betancourt, P.P., Evershed, R.P., 2001. An organic geochemical investigation of the practice of manuring at a Minoan site on Pseira island, Crete. Geoarchaeology 16, 223-242.

Bull, I.D., Lockheart, M.J., Elhmmali, M.M., Roberts, D.J., Evershed, R.P., 2002. The origin of faeces by means of biomarker detection. Environ. Int. 27, 647-654.

Bull, I.D., Elhmmali, M.M., Roberts, D.J., Evershed, R.P., 2003. The application of steroidal biomarkers to track the abandonment of a roman wastewater course at the agora (Athens, Greece). Archaeometry 45, 149-161.

Bull, I.D., Elhmmali, M.M., Perret, V., Matthews, W., Roberts, D.J., Evershed, R.P., 2005. Biomarker evidence of faecal deposition in archaeological sediments at Çatalhöyük. In: Hodder, I. (Ed.), Inhabiting Çatalhöyük: Reports from 1995-1999 Seasons. McDonald Institute monographs, McDonald Institute for Archaeological Research, University of Cambridge, UK, pp. 415-420.

Daudon, M., Estepa, L., Lacour, B., Jungers, P., 1998. Unusual morphology of calcium oxalate calculi in primary hyperoxaluria. J. Nephrol. 11, 51-55.

De Cupere, B. 2001. Animals at Ancient Sagalassos. Evidence of the Faunal Remains (Studies in Eastern Mediterranean Archaeology IV). Brepols Publishers, Turnhout.

De Groote, K., Moens, J., Caluwé, D. Cooremans, B., Deforce, K., Ervynck, A., Lentacker, A., Rijmenants, E., Van Neer, W., Vernaeve, W., Zeebroeck, I., 2004. De Valcke, De Slotele en de Lelye, burgerwoningen op de Grote markt te Aalst: onderzoek naar de bewoners, analyse van een vroeg 16de eeuwse beerputvulling en de evolutie tot stadhuis. Archeologie in Vlaanderen 8, 281-408.

Deforce, K., 2010. Pollen analysis of $15^{\text {th }}$ century cesspits from the palace of the dukes of Burgundy in Bruges (Belgium): evidence for the use of honey from the western Mediterranean. J. Archaeol. Sci. 37, 337-342.

Degryse, P., Muchez, P., Six, S., Waelkens, M., 2003. Identification of ore extraction and metal working in ancient times: a case study of Sagalassos (SW Turkey). J. Geochem. Explor. 77, 65-80.

Degryse, P., Muchez, P., De Cupere, B., Van Neer, W., Waelkens, M., 2004. Statistical Treatment of Trace Element Data from Modern and Ancient Animal Bone: Evaluation of Roman and Byzantine Environmental Pollution. Anal. Lett. 37, 2819-2834.

Dungait, J.A.J., Bol, R., Bull, I.D., Evershed, R.P., 2009. Tracking the fate of dung-derived carbohydrates in a temperate grassland soil using compound-specific stable isotope analysis. Org. Geochem. 40, $1210-1218$.

Dungait, J.A.J., Bol, R., Lopez-Capel, E., Bull, I.D., Chadwick, D., Amelung, W., Granger, S.J., Manning, D.A.C., Evershed, R.P., 2010. Applications of stable isotope ratio mass spectrometry in cattle dung carbon cycling studies. Rapid Commun. Mass Spectrom. 24, 495-500.

Elhmmali, M.M., Roberts, D.J., Evershed, R.P., 1997. Bile acids as a new class of sewage pollution indicator. Environ. Sci. Technol. 31, 3663-3668.

Elhmmali, M.M., Roberts, D.J., Evershed, R.P., 2000. Combined analysis of bile acids and sterols/stanols from riverine particulates to assess sewage discharges and other faecal sources. Environ. Sci. Technol. 34, 39-46.

Entwistle, J.A., Abrahams, P.W., Dodgshon, R.A., 2000. The geoarchaeological significance and spatial sariability of a range of physical and chemical soil properties from a former habitation site, Isle of Skye. J. Archaeol. Sci. 27, 287-303.

Estepa, L., Daudon, M., 1997. Contribution of Fourier Transform Infrared Spectroscopy to the Identification of Urinary Stones and Kidney Crystal Deposits. Biospectroscopopy 3: 347-369.

Evershed, R.P., Bethell, P.H., 1996. Application of multimolecular biomarker techniques to the identification of faecal material in archaeological soils and sediments. ACS Symposium Series 625, 157-172.

Evershed, R.P., Bethell, P.H., Reynolds, P.J., Walsh, N.J., 1997. 5 $\beta$-stigmastanol and related 5 $\beta$-stanols as biomarkers of manuring: analysis of modern experimental material and assessment of the archaeological potential. J. Archaeol. Sci. 24, 485-495.

Faegri, K., Iversen, J., 1989. Textbook of pollen analysis. The Blackburn Press, London.

Farswan, Y.S., Nautiyal, V., 1997. Investigation of phosphorus enrichment in the burial soil of Kumaun, Mid-Central Himalaya, India. J. Archaeol. Sci. 24, 251-258. 
Gaskell, S.J., Eglinton, G., 1975. Rapid hydrogenation of sterols in a contemporary sediment. Nature 254, 209-211.

Ghosh, P., Bhattacharya, S.K., Sahni, A., Kar, R.K., Mohabey, D.M., Ambwani, K., 2003. Dinosaur coprolites from the Late Cretaceous (Maastrichtian) Lameta Formation of India: isotopic and other markers suggesting a C3 plant diet. Cretaceous Res. 24, 743-750.

Gill, F.L., Crump, M.P., Schouten, R., Bull, I.D., 2009. Lipid analysis of a ground sloth coprolite. Quaternary Res. 72, 284-288.

Gill, F.L., Dewhurst, R.J., Dungait, J.A., Evershed, R.P., Ives, L., Li, C.S., Pancost, R.D., Sullivan, M., Bera, S., Bull, I.D., 2010. Archaeol - a biomarker for foregut fermentation in modern and ancient herbivorous mammals? Org. Geochem. 41, 467-472.

Greig, J.R.A., 1981. The investigation of a medieval barrel-latrine from Worcester. J. Archaeol. Sci. 8, 265282.

Greig, J., 1982. Garderobes, sewers, cesspits and latrines. Curr. Archaeol. 85, 49-52.

Grimalt, J.O., Fernández, P., Bayona, J.M., Albaigés, J., 1990. Assessment of faecal sterols and ketones as indicators of urban sewage inputs to coastal waters. Environ. Sci. Technol. 24, 357-363.

Grimm, E., 1991. TILIA and TILIAGRAPH. Illinois State Museum, Springfield.

Jacomet, S. and Kreuz, A., 1999. Archäobotanik: Aufgaben, Methoden und Ergebnisse vegetations- und agrargeschichtlicher Forschung. Ulmer Verlag, Stuttgart.

Knights, B.A., Dickson, C.A., Dickson, J.H., Breeze, D.J., 1983. Evidence concerning the Roman military diet at Beardsen, Scotland, in the $2^{\text {nd }}$ century AD. J. Archaeol. Sci. 10, 139-152.

Kuijper, W.J., Turner, H., 1992. Diet of a Roman centurion at Alphen aan den Rijn, The Netherlands, in the first century AD. Rev. Palaeobot. Palynol. 73, 187-204.

Leeming, R., Ball, A., Ashbolt, N., Nichols, P., 1996. Using faecal sterols from humans and animals to distinguish faecal pollution in receiving waters. Wat. Res. 30, 2893-2900.

Lin, D.S., Conner, W.E., Napton, L.K., Heizer, R.F., 1978. The steroids of 2000-year-old human coprolites. J. Lipid Res. 19, 215-221.

Mackenzie, A.S., Brassell, S.C., Eglinton, G., Maxwell, J.R., 1982. Chemical fossils: the geological fate of steroids. Science 217, 491-504.

MacPhail, R.I., Cruise, G.M., Allen, M.J., Linderholm, J., Reynolds, P., 2004. Archaeological soil and pollen analysis of experimental floor deposits; with special reference to Butser Ancient Farm, Hampshire, UK. J. Archaeol. Sci. 31, 175-191.

Martinez, N.A., 2005. Agriculture and food from the Roman to the IsImaic Period in the North-East of the Iberian peninsula; archaeobotanical studies in the city of Lleida (Catalonia, Spain). Veget. Hist. Archaeobot. 14, 341-361.

Matthews, W., 2010. Geoarchaeology and taphonomy of plant remains and microarchaeological residues in early urban environments in the Ancient Near East. Quatern. Int. 214, 98-113.

McCalley, D.V., Cooke, M., Nickless, G., 1981. Effect of sewage treatment on faecal sterols. Wat. Res. 15, 1019-1025.

McCobb, L.M.E, Briggs, D.E.G., Evershed, R.P., Hall, A.R., Hall, R.A., 2001. Preservation of fossil seeds from a $10^{\text {th }}$ century AD cess pit at Coppergate, York. J. Archaeol. Sci. 18, 929-940.

McCobb, L.M.E., Briggs, D.E.G., Hall, A.R., Kenward, H.K., 2004. The preservation of invertebrates in $16^{\text {th }}-$ century cesspits at St Saviourgate, York. Archaeometry 46, 157-169.

Mehl, J., Kaiser, J., Hurtado, D., Gibson, D.A., Izurieta, R., Mihelcic, J.A., 2011. Pathogen destruction and solids decomposition in composting latrines: study of fundamental mechanisms and user operation in rural Panama. J. Wat. Health 9, 187-199.

Mitchell, P., Tepper, Y. 2007. Intestinal parasitic worm eggs from a crusader period cesspool in the city of Acre (Israel). Levant 39, 91-95.

Oeggl, K., Schmidl, A., Kofler, W., 2009. Origin and seasonality of subfossil caprine dung from the discovery site of the Iceman (Eastern Alps). Veget. Hist. Archaeobot. 18, 37-46.

Parnell, J.J, Terry, R.E., Golden, C., 2001. Using in-field phosphate testing to rapidly identify middens at Piedras Negras, Guatemala. Geoarchaeology 16, 855-873.

Pepe, C., Dizabo, P., Scribe, P., Dagaut, J., Fillaux, J., Saliot, A., 1989. Les marqueurs biogéochimiques: application à l'archéologie. Revue d' Archéométrie 13, 1-12.

Pepe, C., Dizabo, P., 1990. Étude d'une fosse du 13ème siècle par les marqueurs biogéochimiques: chantier archéologique du Louvre (Paris). Revue d'Archéométrie 14, 23-28.

Poblome, J., Corremans, M., Bes, P., Romanus, K., Degryse, P., 2008. It is never too late... the late Roman initiation of amphora production in the territory of Sagalassos. In: Delemen, I., Cokay-Kepçe, S., Özdibay, A. (eds.), Prof Dr Haluk Abbasoglu'na 65. Yas Armagan. Studies presented tot Prof Dr Haluk Abbasoglu. Akmed, Istanbul, Turkey, pp 1001-1012.

Prance, G., Nesbitt, M., 2005. The cultural history of plants. Routledge, New York.

Ramsay, J., Tepper, Y., 2010. Signs from a green desert: a preliminary examination of the archaeobotanical remains from a Byzantine dovecote near Shivta, Israel. Veget. Hist. Archaeobot. 19, 235-242.

Reimer, P.J., Baillie, M.G.L., Bard, E., Bayliss, A., Beck, J.W., Bertrand, C.J.H., Blackwell, P.G., Buck, C.E., Burr, G.S., Cutler, K.B., Damon, P.E., Edwards, R.L., Fairbanks, R.G., Friedrich, M., Guilderson, T.P., Hogg, A.G., Hughen, K.A., Kromer, B., McCormac, G., Manning, S., Ramsey, C.B., Reimer, 
R.W., Remmele, S., Southon, J.R., Stuiver, M., Talamo, S., Taylor, F.W., van der Plicht, J., Weyhenmeyer, C.E., 2004. INTCAL04 terrestrial radiocarbon age calibration, 0-26 cal kyr BP. Radiocarbon 46, 1029-1058.

Reinhard, K.J., 1992. Parasitology as an interpretive tool in archaeology. Am. Antiquity 57, 231-245.

Romanus, K., Baeten, J., Poblome, J., Accardo, S., Degryse, P., Jacobs, P., De Vos, D., Waelkens, M., 2009. Wine and olive oil permeation in pitched and non-pitched ceramics: relation with results from archaeological amphorae from Sagalassos, Turkey. J. Archaeol. Sci. 36, 900-909.

Scobie, A., 1986. Slums, sanitation and mortality in the Roman world. Klio 68, 399-433.

Shahack-Gross, R., 2011. Herbivorous livestock dung: formation, taphonomy, methods for identification, and archaeological significance. J. Archaeol. Sci. 38, 205-218.

Shahack-Gross, R., Finkelstein, I., 2008. Subsistence practices in an arid environment: a geoarchaeological investigation in an Iron Age site, the Negev Highlands, Israel. J. Archaeol. Sci. 35, 965-982.

Shillito, L.-M., Bull, I.D., Matthews, W., Almond, M.J., Williams, J.M., Evershed, R.P., 2011a. Biomolecular and micromorphological analysis of suspected faecal deposits at Neolithic Çatalhöyük, Turkey. J. Archaeol. Sci. 38, 1869-1877.

Shillito, L.-M., Matthews, W., Almond, M.J., Bull, I.D., 2011b. The microstratigraphy of middens: capturing daily routine in rubbish at Neolithic Çatalhöyük, Turkey. Antiquity 85, 1024-1038.

Simpson, I.A., 1997. Relict properties of anthropogenic deep top soils as indicators of infield management in Marwick, West Mainland, Orkney. J. Archaeol. Sci. 24, 365-380.

Simpson, I.A., van Bergen, P.F., Perret, V., Elhmmali, M.M., Roberts, D.J., Evershed, R.P., 1999a. Lipid biomarkers of manuring practice in relict anthropogenic soils. Holocene 9, 223-229.

Simpson, I.A., Bol, R., Bull, I.D., Evershed, R.P., Petzke, K.J., Dockrill, S.J., 1999b. Interpreting early land management through compound specific stable isotope analysis of archaeological soils. Rapid Commun. Mass Spectrom. 13, 1315-1319.

Taylor, C.D., Smith, S.O., Gagosian, R.B., 1981. Use of microbial enrichments for the study of the anaerobic degradation of cholesterol. Geochim. Cosmochim. Ac. 45, 2161-2168.

Tyson, R.C., 1996. Medieval glass vessels in England AD 1200-1500 : a survey. PhD thesis, Durham University.

van Geel, B., 1978. A palaeoecological study of Holocene peat bog sections in Germany and the Netherlands. Rev. Palaeobot. Palynol. 25, 1-120.

van Geel, B., 1986. Application of fungal and algal remains and other microfossils in palynological analyses. In: Berglund, B.E. (Ed.), Handbook of Holocene Palaeoecology and Palaeohydrology. J. Wiley, Chichester, pp. 497-505

van Geel, B., Pals, J.P., van Reenen, G.B., van Huissteden, J., 1995. The indicator value of fossil fungal remains, illustrated by a palaeoecological record of a Late Eemian/Early Weichselian deposit in the Netherlands. In: Herngreen, G.F.W., van derValk, L. (Eds.), Neogene and Quaternary geology of North-West EuropeMeded. Rijks Geol. Dienst, vol. 52, pp. 297-315.

van Geel, B., 2001. Non-pollen palynomorphs. In: Smol, J.P., Birks, H.J.B., Last, W.M. (Eds.), Terrestrial, algal and siliceous indicators. Tracking environmental changes using lake sediments, vol. 3. Kluwer Academic Press, Dordrecht, pp. 99-119.

van Geel, B., Buurman, J., Brinkkemper, O., Schelvis, J., Aptroot, A., van Reenen, G., Hakbijl, T., 2003. Environmental reconstruction of a Roman Period settlement site in Uitgeest (The Netherlands), with special reference to coprophilous fungi. J. Archaeol. Sci. 30, 873-883.

van Geel, B., Aptroot, A., Baittinger, C., Birks, H.H., Bull, I.D., Cross, H.B., Evershed, R.P., Gravendeel, B., Kompanje, E.J.O., Kuperus, P., Mol, D., Nierop, K.G.J., Pals, J.P., Tikhonov, A.N., van Reenen, G., van Tienderen, P.H., 2008. The ecological implications of a Yakutian mammoth's last meal. Quaternary Res. 69, 361-376.

van Geel, B., Guthrie, R.D., Altmann, J.G., Broekens, P., Bull, I.D., Gill, F.L., Jansen, B., Nieman, A.M., Gravendeel, B., (in press). Mycological evidence of coprophagy from the faeces of an Alaskan Late Glacial mammoth. Quaternary Sci. Rev. doi:10.1016/j.quascirev.2010.03.008.

van Graas, G., Baas, J.M., van de Graaf, B., de Leeuw, J.W., 1982. Theoretical organic geochemistry. I. The thermodynamic stability of several cholestane isomers calculated by molecular mechanics. Geochim. Cosmochim. Ac. 46, 2399-2402.

Vanhaverbeke, H., Waelkens, M., 2003. The Chora of Sagalassos. The Evolution of the Settlement Pattern in the Territory of Sagalassos from Prehistoric until Recent Times. Studies in Eastern Mediterranean Archaeology V, Brepols publisher, Turnhout, Belgium.

Vermoere, M., Six, S., Poblome, J., Degryse, P., Paulissen, E., Waelkens, M., Smets, E., 2003. Pollen Sequences from the City of Sagalassos (Pisidia, Southwest Turkey). Anatolian Studies 53, 161-173.

Vermoere, M., 2004. Holocene vegetation history in the territory of Sagalassos (Southwest Turkey) A palynological approach. Studies in Eastern Mediterranean Archaeology VI. Brepols publisher, Turnhout, Belgium.

Waelkens, M., Vanhaverbeke, H., Martens, F., Talloen, P., Poblome, J., Uytterhoeven, I., Kellens, N., Putzeys, T., Degryse, P., Van Thuyne, T., Van Neer, W., 2006. The Late Antique to Early Byzantine City in Southwest Anatolia. Sagalassos and its territory: a case study' In: Krause, J.-U, Witschel, C. (Eds.), Die Stadt in der Spätantike - Niedergang oder Wandel? Akten des Internationalen Kolloquiums in München am 30. und 31. Mai 2003, Stuttgart. pp. 199-255. 


\section{KU LEUVEN}

White, K.D., 1970. Roman farming. Cornell University Press, New York.

Wilkinson, T.J., 1982. The definition of ancient manured zones by means of extensive sherd-sampling techniques. J. Field Archaeol. 9, 323-333. 


\section{KU LEUVEN}

\section{LIST OF FIGURES}

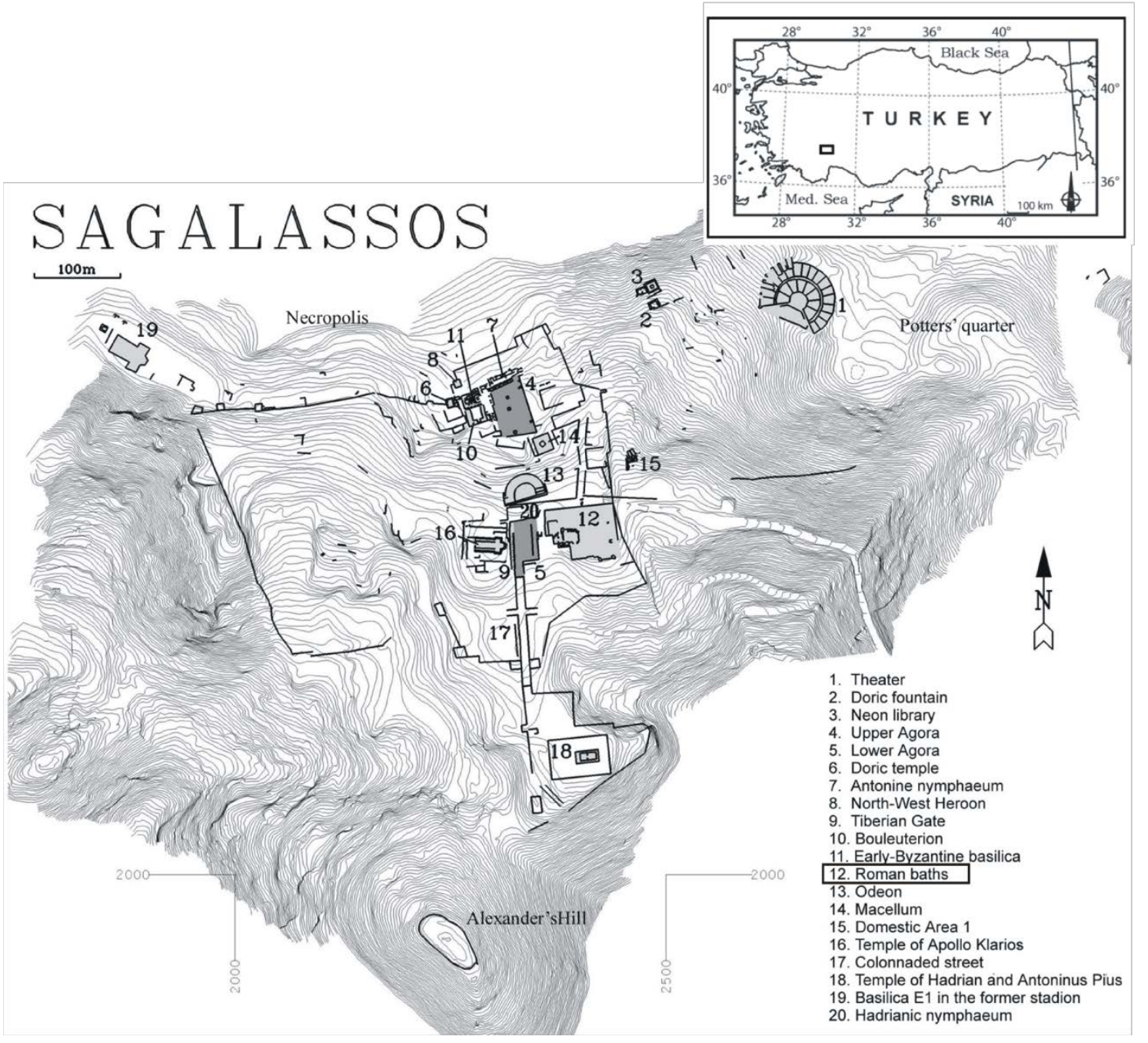

Figure 1. Location and site map of Sagalassos. 


\section{KU LEUVEN}

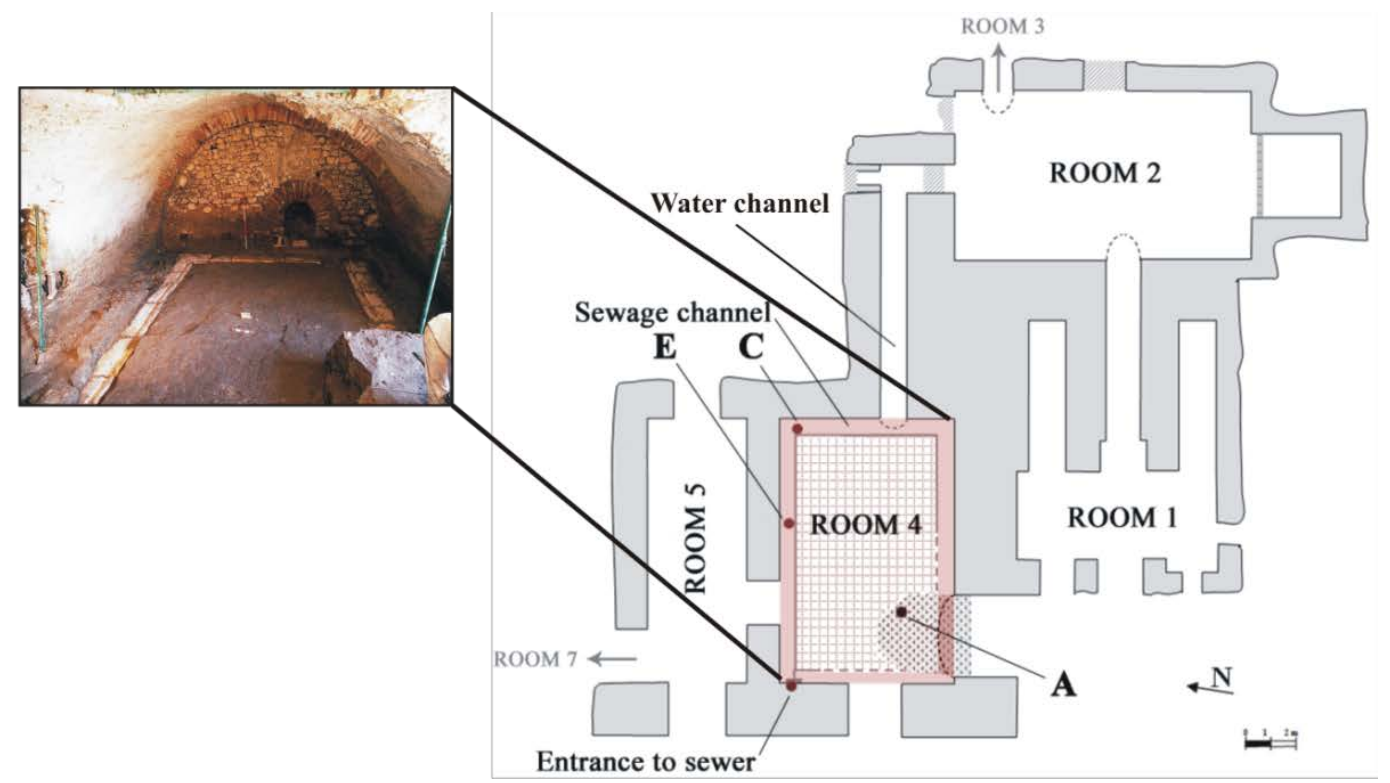

Profile A

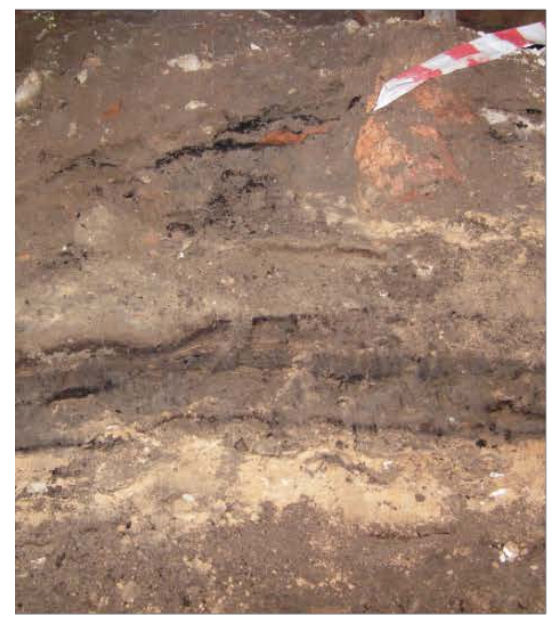

Legend:
Profile representative for location $\mathbf{C}$ and $\mathbf{E}$

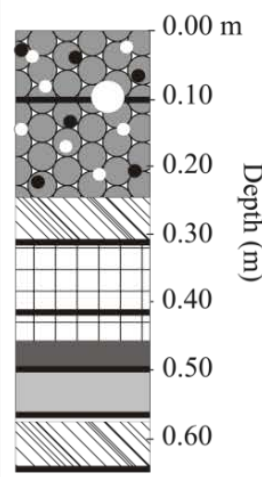

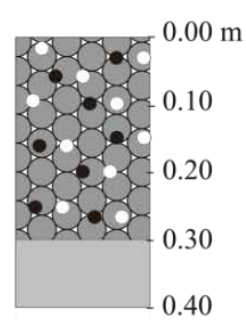

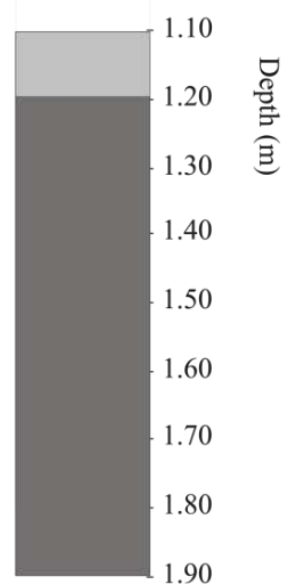

Figure 2. Map of the ground floor of the bath complex of Sagalassos with location and stratigraphic description of the core profiles in room 4 and 5. 


\section{KULEUVEN}

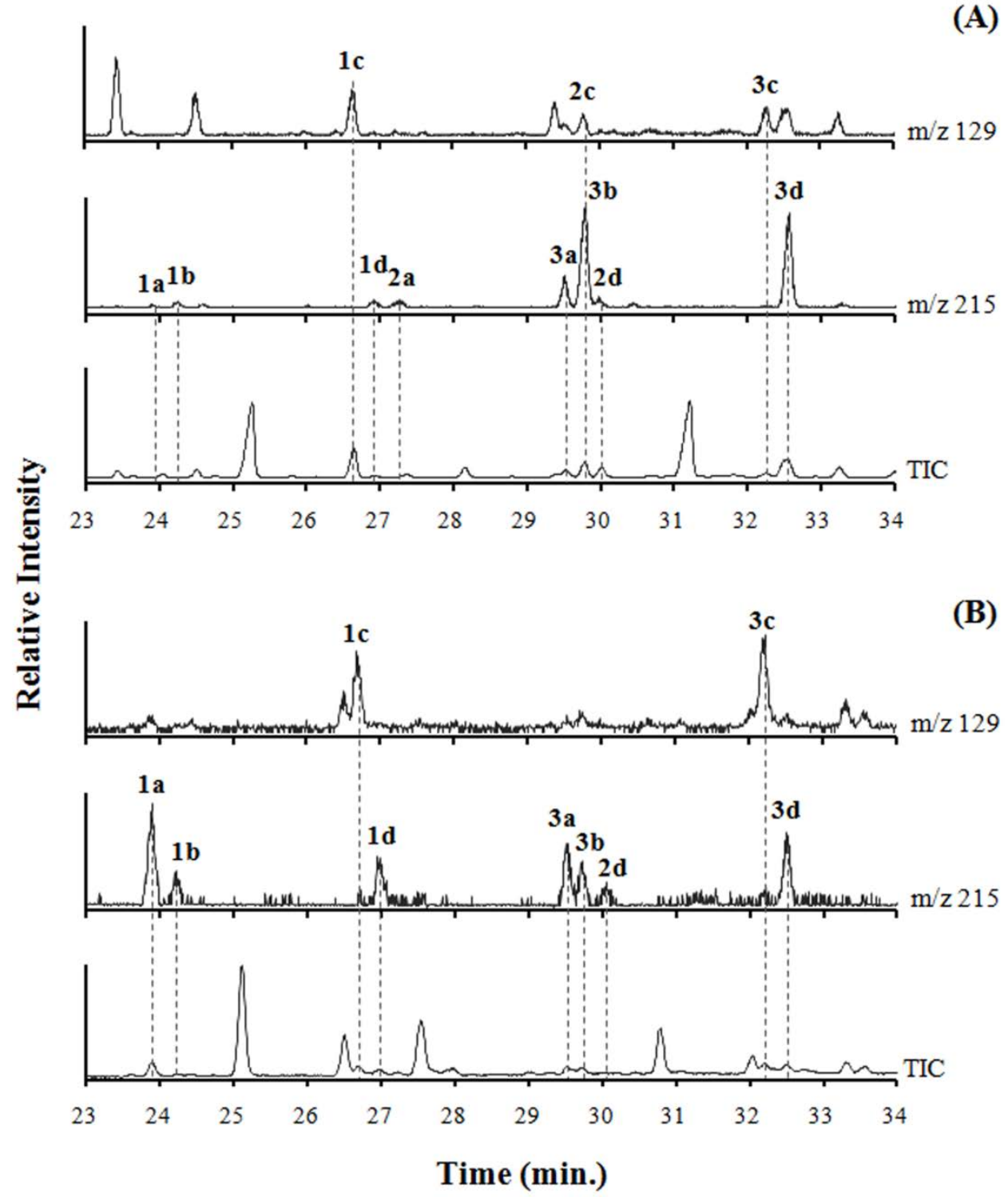

Figure 3. Selected ion $(\mathrm{m} / \mathrm{z} 129,215)$ and corresponding total ion chromatograms of the neutral fraction of samples from (A) deepest sample from locus $A(0$ to $15 \mathrm{~cm}$ above original floor) and (B) deepest sample from locus C (130 to $140 \mathrm{~cm}$ depth). Labelled peaks represent coprostanol (1a), epicoprostanol (1b),

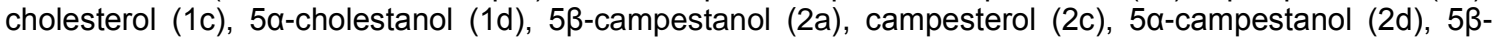
stigmastanol (3a), epi-5ß-stigmastanol (3b), sitosterol (3c) and $5 \alpha$-stigmastanol (3d). 

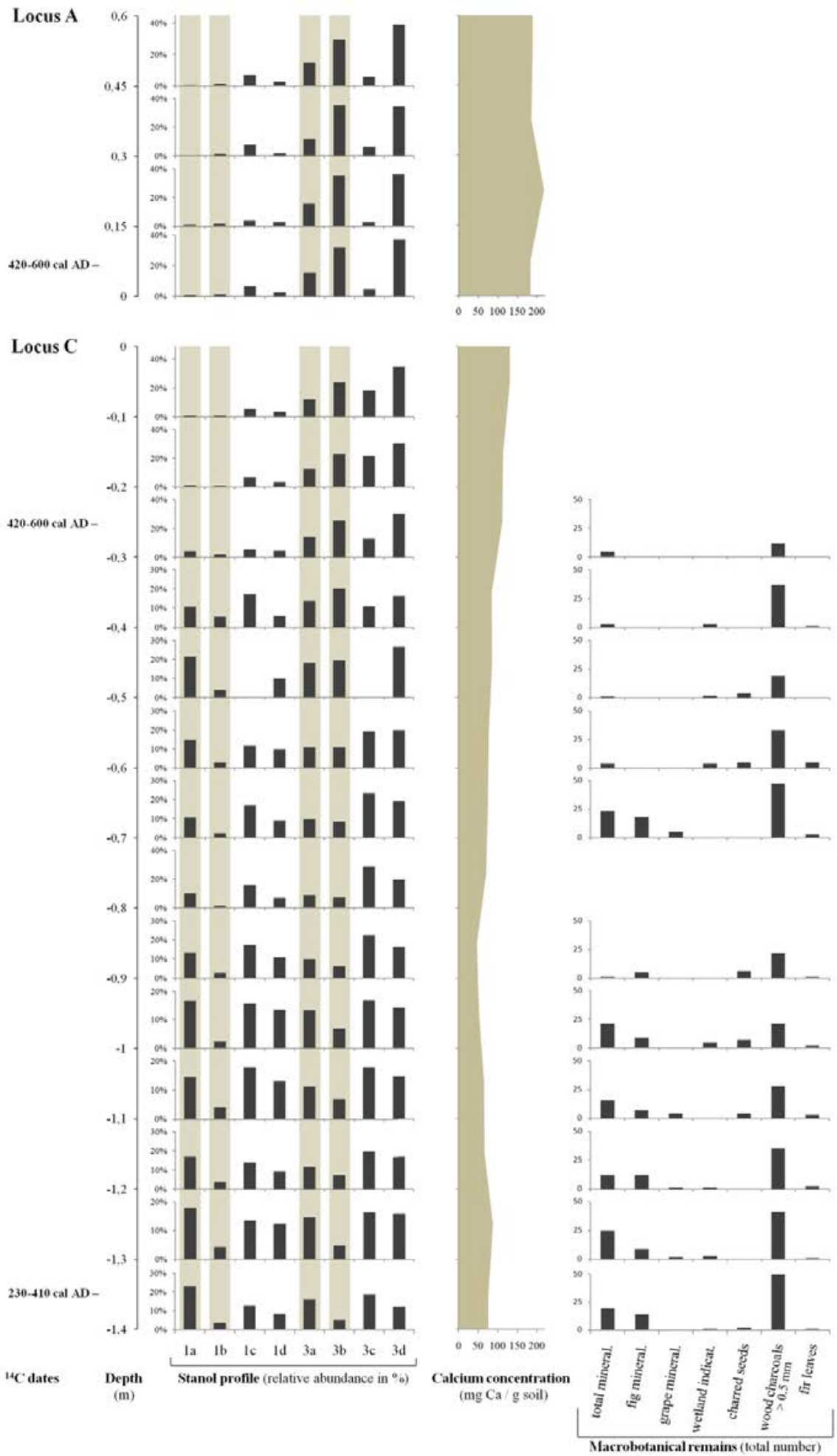

Figure 4. Combined results of faecal biomarker analysis, elemental (Ca) analysis and analysis of macrobotanical remains of the latrine sediment cores. Depths are expressed relative to original floor level with positive and negative values reflecting samples above and beneath floor level, respectively. Sediment dates are expressed as the 2 sigma calibration interval resulting from radiocarbon dating. The location of the different soil profiles is indicated in figure 2. Labelled compounds represent coprostanol (1a),

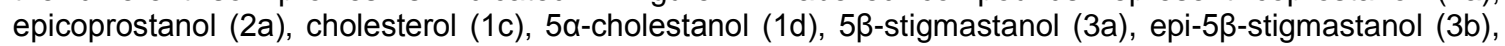
sitosterol (3c) and 5a-stigmastanol (3d). Chemical structures of the steroids are given in figure S1. 


\section{KU LEUVEN}

Locus E
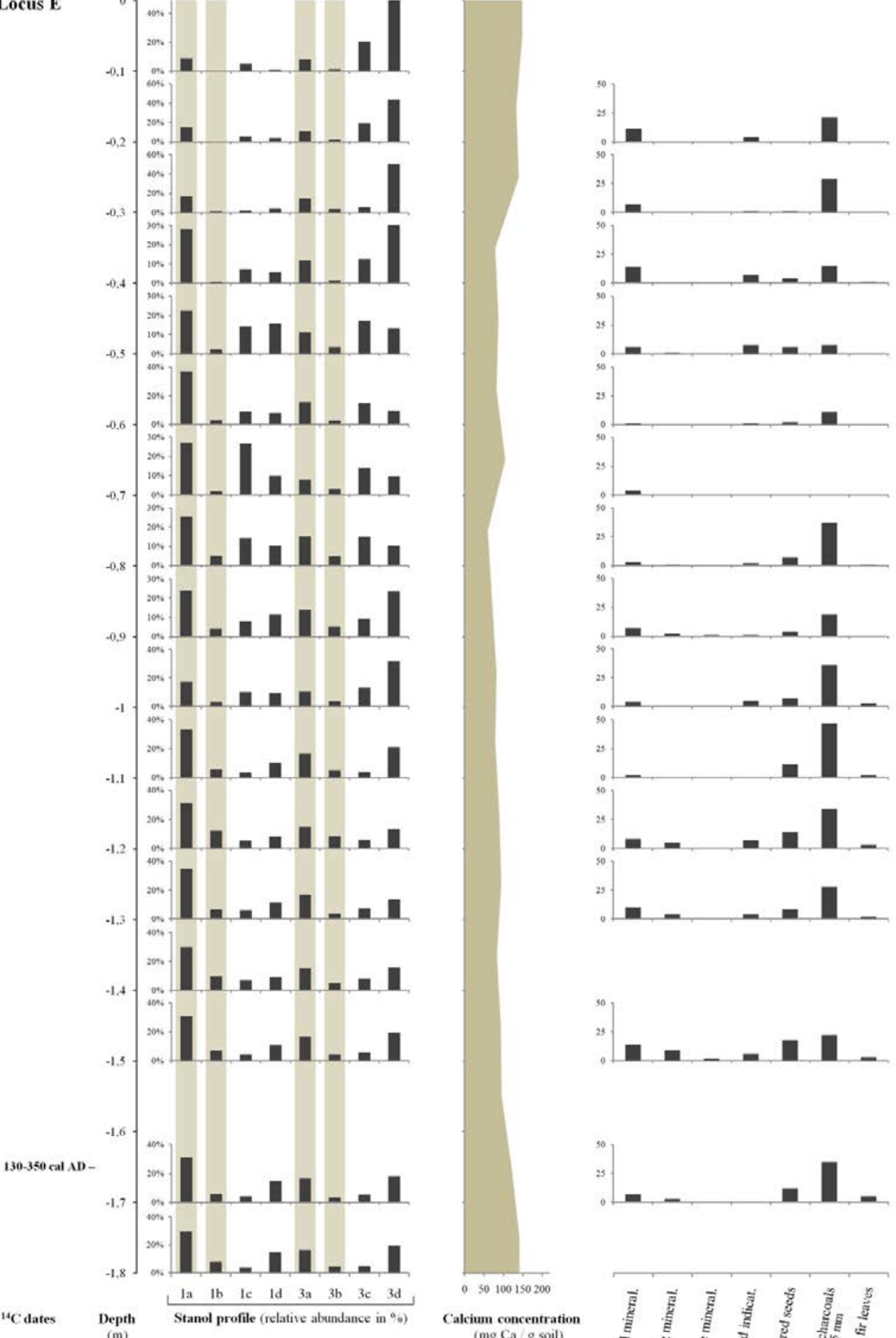

50100150200

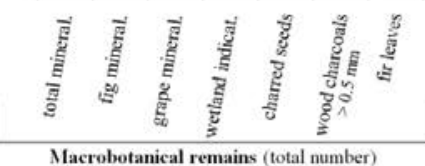

Figure 4 (continued) 

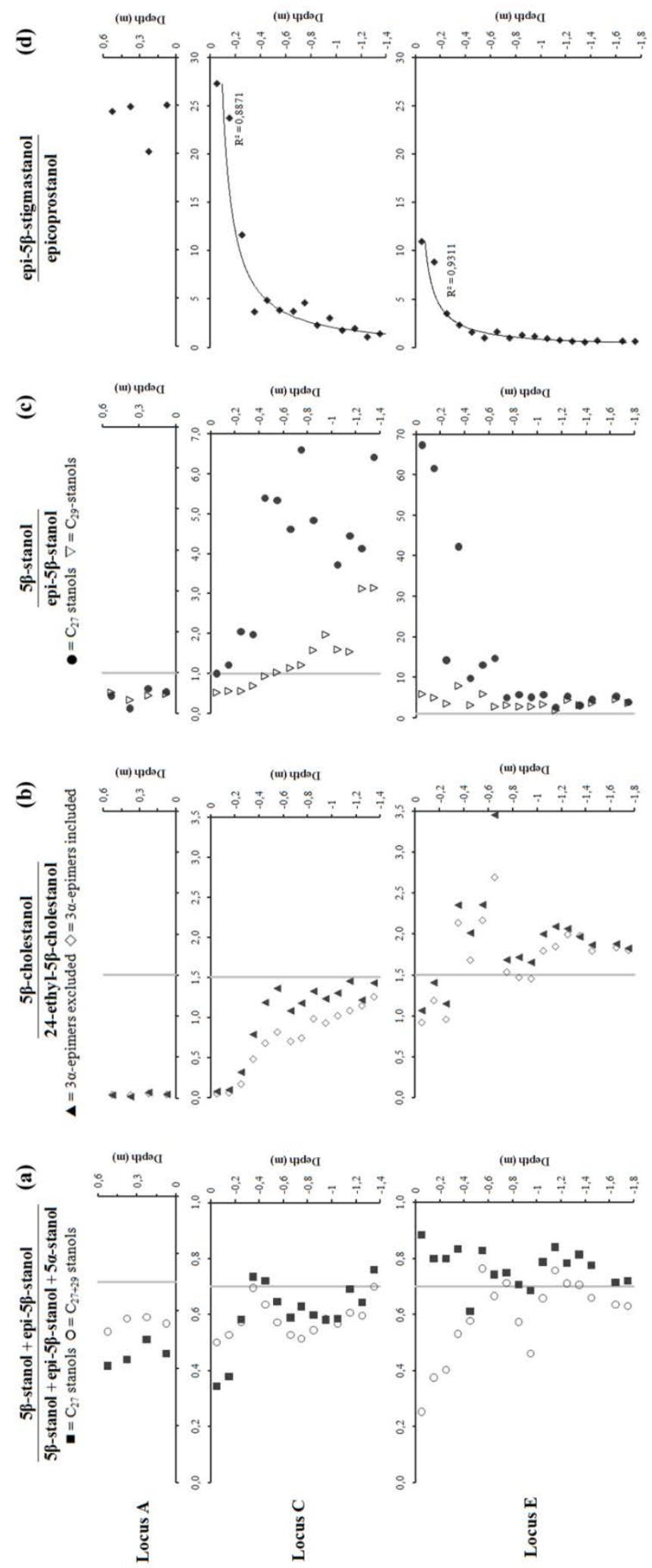

Figure 5. Summary of the stanol ratios for the latrine sediments: (a) $[5 \beta:(5 \beta+5 \alpha)]$ ratio of $C 27$ and C27+29 stanols (filled squares and open circles respectively), (b) [coprostanol : $5 \beta$-stigmastanol] ratio (filled

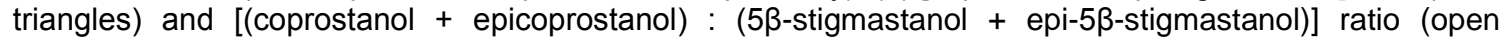

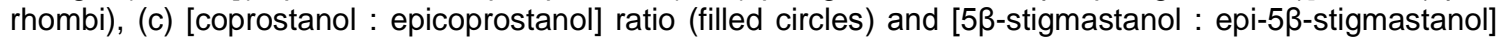
ratio (open triangles), and (d) [epi-5 $\beta$-stigmastanol : epicoprostanol] ratio. Depths are expressed relative to original floor level with positive and negative values reflecting samples above and beneath floor level, respectively. The location of the soil profiles is indicated in figure 2. Chemical structures of the steroids are given in figure S1. 


\section{KU LEUVEN}

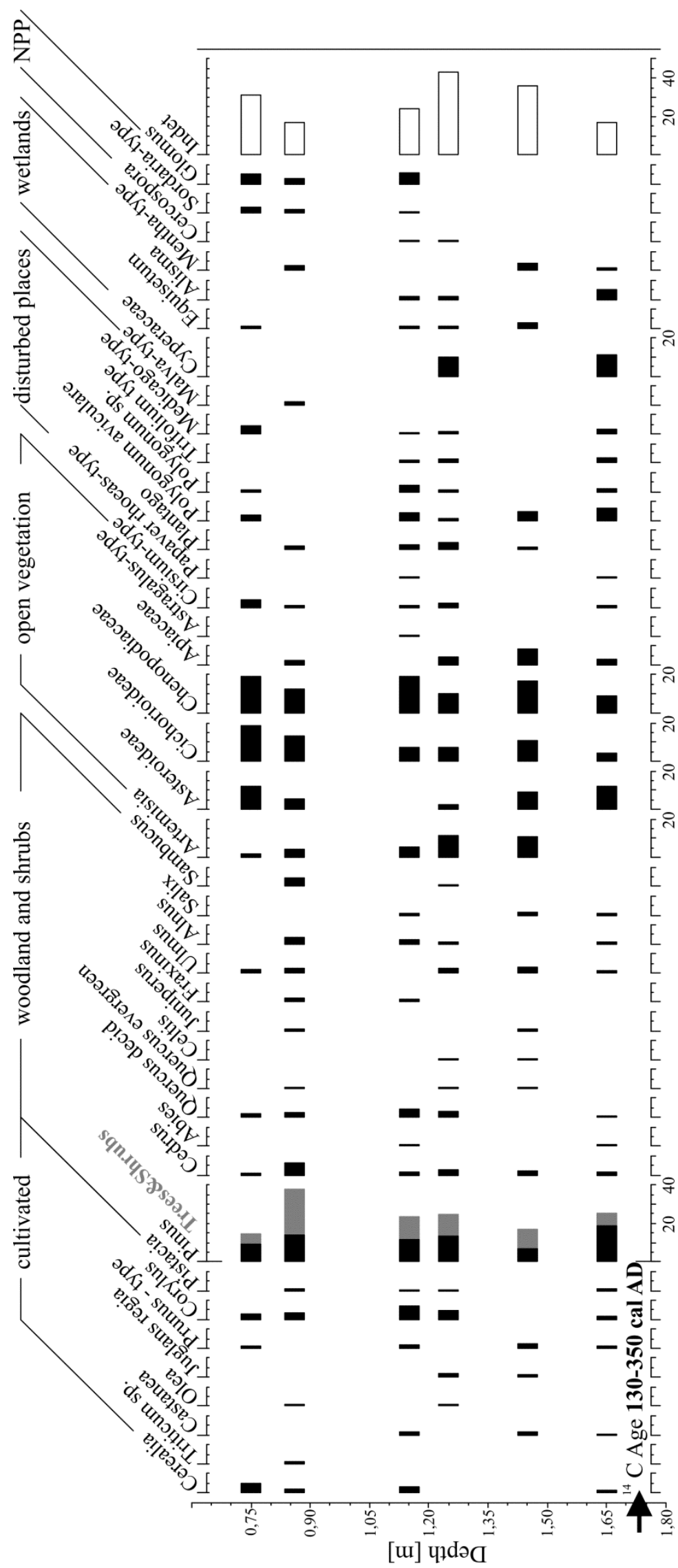

Figure 6. Percentage pollen diagram of the lower part of the sewage channel core (locus E). 


\section{LIST OF TABLES}

Table 1. Summary of sampled sediment layers per locus with their stratigraphic category and applied methods. The location of the sediment cores is indicated in figure 2.

\begin{tabular}{|c|c|c|c|c|c|c|c|}
\hline Sample number & Depth $(m)^{a}$ & Stratigraphy $^{\mathrm{b}}$ & pH & $\begin{array}{l}\text { Faecal } \\
\text { biomarkers }\end{array}$ & $\mathbf{C a}$ & Macroremains & Pollen \\
\hline \multicolumn{8}{|c|}{ Locus C - sewage channel in northeastern corner } \\
\hline SA08GV1263 & {$[0 ;-0.1]$} & 1 & & $\bullet$ & $\bullet$ & & \\
\hline SA08GV1264 & {$[-0.1 ;-0.2]$} & 1 & 7.8 & $\bullet$ & $\bullet$ & & \\
\hline SA08GV1265 & {$[-0.2 ;-0.3]$} & 1 & & $\bullet$ & $\bullet$ & $\bullet$ & \\
\hline SA08GV1266 & {$[-0.3 ;-0.4]$} & 5 & & $\bullet$ & $\bullet$ & $\bullet$ & \\
\hline SA08GV1267 & {$[-0.4 ;-0.5]$} & 5 & 7.5 & $\bullet$ & $\bullet$ & $\bullet$ & \\
\hline SA08GV1268 & {$[-0.5 ;-0.6]$} & 5 & & $\bullet$ & $\bullet$ & $\bullet$ & \\
\hline SA08GV1269 & {$[-0.6 ;-0.7]$} & 5 & & $\bullet$ & $\bullet$ & $\bullet$ & \\
\hline SA08GV1270 & {$[-0.7 ;-0.8]$} & 5 & & $\bullet$ & $\bullet$ & & \\
\hline SA08GV1271 & {$[-0.8 ;-0.9]$} & 5 & 7.7 & $\bullet$ & $\bullet$ & $\bullet$ & \\
\hline SA08GV1272 & {$[-0.9 ;-1.0]$} & 5 & & $\bullet$ & $\bullet$ & $\bullet$ & \\
\hline SA08GV1273 & {$[-1.0 ;-1.1]$} & 5 & & $\bullet$ & $\bullet$ & $\bullet$ & \\
\hline SA08GV1274 & {$[-1.1 ;-1.2]$} & 5 & 7.7 & $\bullet$ & $\bullet$ & $\bullet$ & \\
\hline SA08GV1275 & {$[-1.2 ;-1.3]$} & 4 & & $\bullet$ & $\bullet$ & $\bullet$ & \\
\hline SA08GV1276" & {$[-1.3 ;-1.4]$} & 4 & 7.5 & $\bullet$ & $\bullet$ & $\bullet$ & \\
\hline \multicolumn{8}{|c|}{ Locus E - sewage channel in middle of northern wall } \\
\hline SA08GV1277 & {$[0 ;-0.1]$} & 1 & & $\bullet$ & $\bullet$ & & \\
\hline SA08GV1278 & {$[-0.1 ;-0.2]$} & 1 & & $\bullet$ & $\bullet$ & $\bullet$ & \\
\hline SA08GV1279 & {$[-0.2 ;-0.3]$} & 1 & 7.7 & $\bullet$ & $\bullet$ & $\bullet$ & \\
\hline SA08GV1280 & {$[-0.3 ;-0.4]$} & 5 & & $\bullet$ & $\bullet$ & $\bullet$ & \\
\hline SA08GV1281 & {$[-0.4 ;-0.5]$} & 5 & & $\bullet$ & $\bullet$ & $\bullet$ & \\
\hline SA08GV1282 & {$[-0.5 ;-0.6]$} & 5 & 7.5 & $\bullet$ & $\bullet$ & $\bullet$ & \\
\hline SA08GV1283 & {$[-0.6 ;-0.7]$} & 5 & & $\bullet$ & $\bullet$ & $\bullet$ & \\
\hline SA08GV1284 & {$[-0.7 ;-0.8]$} & 5 & & $\bullet$ & $\bullet$ & $\bullet$ & $\bullet$ \\
\hline SA08GV1285 & {$[-0.8 ;-0.9]$} & 5 & & $\bullet$ & $\bullet$ & $\bullet$ & $\bullet$ \\
\hline SA08GV1286 & {$[-0.9 ;-1.0]$} & 5 & & $\bullet$ & $\bullet$ & $\bullet$ & \\
\hline SA08GV1287 & {$[-1.0 ;-1.1]$} & 5 & & $\bullet$ & $\bullet$ & $\bullet$ & \\
\hline SA08GV1288 & {$[-1.1 ;-1.2]$} & 5 & 7.8 & $\bullet$ & $\bullet$ & $\bullet$ & $\bullet$ \\
\hline SA08GV1289 & {$[-1.2 ;-1.3]$} & 4 & 7.7 & $\bullet$ & $\bullet$ & $\bullet$ & $\bullet$ \\
\hline SA08GV1290 & {$[-1.3 ;-1.4]$} & 4 & 7.7 & $\bullet$ & $\bullet$ & & \\
\hline SA08GV1291 & {$[-1.4:-1.5]$} & 4 & & $\bullet$ & $\bullet$ & $\bullet$ & $\bullet$ \\
\hline SA08GV1292 & {$[-1.5 ;-1.6]$} & 4 & & $\bullet$ & $\bullet$ & & \\
\hline SA08GV1293" & {$[-1.6 ;-1.7]$} & 4 & 7.6 & • & $\bullet$ & $\bullet$ & $\bullet$ \\
\hline SA08GV1294 & {$[-1.7 ;-1.8]$} & 4 & & $\bullet$ & $\bullet$ & & \\
\hline \multicolumn{8}{|c|}{ Locus A - heap close to southwestern window } \\
\hline SA08GV1259-4 & {$[0.60 ; 0.45]$} & $4,5,6$ & & $\bullet$ & $\bullet$ & & \\
\hline SA08GV1259-3 & {$[0.45 ; 0.30]$} & 3,6 & 7.8 & $\bullet$ & $\bullet$ & & \\
\hline SA08GV1259-2 & {$[0.30 ; 0.15]$} & 1,2 & 7.6 & $\bullet$ & $\bullet$ & & \\
\hline SA08GV1259-1 ${ }^{\pi}$ & {$[0.15 ; 0]$} & 1,6 & 7.9 & $\bullet$ & $\bullet$ & & \\
\hline
\end{tabular}

Published version: http://dx.doi.org/10.1016/j.jas.2011.12.019

Journal homepage: http://www.journals.elsevier.com/journal-of-archaeological-science/ 


\section{KULEUVEN}

Table 2. $A M S{ }^{14} \mathrm{C}$ dates of the latrine deposits

\begin{tabular}{|c|c|c|c|c|c|c|c|}
\hline Sample & Locus & $\begin{array}{l}\text { Depth } \\
(\mathrm{m})^{\mathrm{a}}\end{array}$ & $\begin{array}{l}\text { Laboratory } \\
\text { Code }\end{array}$ & $\begin{array}{l}\delta^{13} \mathrm{C} \text { (\%o } \\
\text { PDB) }\end{array}$ & $\begin{array}{l}\text { Conventional } \\
{ }^{14} \mathrm{C} \text { age (BP) }\end{array}$ & $\begin{array}{l}\text { Cal. } \\
\text { age }^{\text {b }}\end{array}$ & $\begin{array}{ll}\text { Cal. } & \quad 10 \\
\text { age }^{c} & \\
\end{array}$ \\
\hline SA08GV1259 & A & {$[0 ; 0.15]$} & Beta-281735 & -24.1 & $1550 \pm 40$ & AD 420-600 & AD 430-560 \\
\hline SA08GV1265 & C & $-[0.2 ; 0.3]$ & Beta-284661 & -22.0 & $1550 \pm 40$ & AD 420-600 & AD 430-560 \\
\hline SA08GV1276 & C & $-[1.3 ; 1.4]$ & Beta-281733 & -24.9 & $1730 \pm 40$ & AD 230-410 & AD 250-380 \\
\hline SA08GV1293 & $E$ & $-[1.6 ; 1.7]$ & Beta-281734 & -22.2 & $1780 \pm 40$ & AD 130-350 & AD 220-320 \\
\hline
\end{tabular}

${ }^{a}$ Relative to original floor level; positive and negative values reflect depths above and beneath floor level, respectively.

${ }^{b} 95 \%$ probability

${ }^{c} 68 \%$ probability

Table 3. Mass spectrometric details of sterols and stanols

\begin{tabular}{|c|c|c|}
\hline Compound & $\begin{array}{l}\text { Diagnostic } \\
\text { fragments }(\mathrm{m} / \mathrm{z})\end{array}$ & Fragment origin \\
\hline $5 \alpha / 5 \beta$ stanols & 215 & {$[\mathrm{M}-\mathrm{TMSOH} \text { - Side chain }-42]^{+}$} \\
\hline cholestan-3-ol & 370 & {$\left[\mathrm{M}-\mathrm{TMSOH}^{+}\right.$} \\
\hline 24-methylcholestan-3-ol & 384 & {$[\mathrm{M}-\mathrm{TMSOH}]^{+}$} \\
\hline 24-ethylcholestan-3-ol & 398 & {$\left[\mathrm{M}-\mathrm{TMSOH}^{+}\right.$} \\
\hline$\Delta^{\mathrm{s}}$ sterols & 129 & A-ring fission \\
\hline 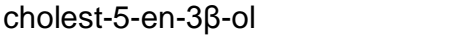 & 368 & {$[\mathrm{M}-\mathrm{TMSOH}]^{+}$} \\
\hline 24-methylcholest-5-en-3ß-ol & 382 & {$\left[\mathrm{M}-\mathrm{TMSOH}^{+}\right.$} \\
\hline 24-ethylcholesta-5,22-dien-3ß-ol & 394 & {$[\mathrm{M}-\mathrm{TMSOH}]^{+}$} \\
\hline 24-ethylcholest-5-en-3ß-ol & 396 & {$[\mathrm{M}-\mathrm{TMSOH}]^{+}$} \\
\hline
\end{tabular}



Research Coordination Office

Huis Bethlehem

Schapenstraat 34

B-3000 Leuven

Tel.: +3216324065

Fax: +3216324198

onderzoek@kuleuven.be

www.kuleuven.be 